Electronic Supplementary Information for:

\title{
Tetraphenylethene-Functionalized Conjugated Helical Poly(phenyl isocyanide) with Tunable Light Emission, Assembly Morphology, and Specific Applications
}

\author{
Ya-Guang He, Sheng-Yu Shi, Na Liu, Yun-Sheng Ding, Jun Yin,* and Zong-Quan Wu*
}

Department of Polymer Science and Engineering, School of Chemistry and Chemical Engineering, Hefei

University of Technology and Anhui Key Laboratory of Advanced Functional Materials and Devices, Hefei 230009, China

E-mail: yinjun@hfut.edu.cn (J.Y.), zqwu@hfut.edu.cn (Z.-Q.W.). 


\section{Instruments}

All the ${ }^{1} \mathrm{H},{ }^{13} \mathrm{C}$, and ${ }^{31} \mathrm{P}$ nuclear magnetic resonance (NMR) spectra were recorded using a Bruker 600 or $400 \mathrm{MHz}$ spectrometer operated in the Fourier Transform mode. Molecular weights and molecular weight distributions were determined using a size exclusion chromatograms (SEC) equipped with a Waters 1515 pump and a Waters 2414 differential refractive index detector (set at $40^{\circ} \mathrm{C}$ ). A series of three linear Styragel columns (HR0.5, HR2, and HR4; $3.6 \times 300 \mathrm{~mm}$ ) was used at a temperature of $40{ }^{\circ} \mathrm{C}$. The eluent used was THF at a flow rate of $0.3 \mathrm{~mL} / \mathrm{min}$. FT-IR spectra were recorded on Perkin-Elmer Spectrum BX FT-IR system using $\mathrm{KBr}$ pellets. UV-vis spectra were performed on a UNIC 4802 UV/VIS double beam spectrophotometer in $1.0 \mathrm{~cm}$ length quartz cell. Fluorescence spectra were recorded using a RF-5301/PC (Shimadzu) spectrofluorometer. The temperature of the water-jacketed cell holder was controlled by a programmable circulation bath. The slit widths were set at $5.0 \mathrm{~nm}$ for both excitation and emission. Thermogravimetric analysis (TGA) test was performed in nitrogen atmosphere at a heating rate of $10{ }^{\circ} \mathrm{C}$ $\min ^{-1}$ from 100 to $850{ }^{\circ} \mathrm{C}$ using a Netzsch TG 209 F3 instrument. Differential scanning calorimetric (DSC) measurements were carried on a Mettler-Toledo DSC821e instrument. Samples were first heated from 25 to $150{ }^{\circ} \mathrm{C}$ at a heating rate of $10{ }^{\circ} \mathrm{C} \mathrm{min}^{-1}$ under nitrogen atmosphere and kept constant at $150{ }^{\circ} \mathrm{C}$ for 5 min, followed by cooling to $25{ }^{\circ} \mathrm{C}$ at $10{ }^{\circ} \mathrm{C} \min ^{-1}$ and finally heating to $400{ }^{\circ} \mathrm{C}$ again at $10{ }^{\circ} \mathrm{C} \min ^{-1}$. Glass transition temperature $\left(\mathrm{T}_{\mathrm{g}}\right)$ was determined as the midpoint of the transition of the second heating sequence. Transmission electron microscopy (TEM) observations were conducted on a JEM-2100F electron microscope operating at an acceleration voltage of $200 \mathrm{kV}$. The samples for TEM observation were prepared by casting the corresponding solutions of polymers onto copper mesh grids and drying in air at room temperature. Samples for atomic force microscopy (AFM) measurements were prepared by drop casting solutions of polymers onto pre-cleaned silicon wafers and drying in air at room temperature. AFM images were obtained in tapping mode with a Digital Instruments Dimension 3100 Scanning Probe Microscope, 
performed at room temperature in air using standard silicon cantilevers with a nominal spring constant of 50 $\mathrm{N} / \mathrm{m}$ and resonance frequency of $\sim 300 \mathrm{kHz}$. Dynamic light scattering (DLS) measurements were carried on a Nano-ZS90 Zetasizer of Malvern (UK) instrument, all data were averaged over three time measurements. Integrating sphere was used to measure the fluorescence quantum yields (FFs) of the solid powers. FFs of the mixture solutions with varied solvent compositions $\left(\mathrm{THF} / \mathrm{H}_{2} \mathrm{O}\right)$ were determined by comparison with a quinine sulfate standard $\left(10^{-5} \mathrm{M}\right.$ in $\left.0.1 \mathrm{~N} \mathrm{H}_{2} \mathrm{SO}_{4}, \mathrm{FF}=0.55\right)$.

\section{Materials}

All solvents were obtained from Sinopharm. Co. Ltd. and were purified by the standard procedures before use. THF was further dried over sodium benzophenone ketyl and distilled onto $\mathrm{LiAlH}_{4}$ under nitrogen just before use. 4-Hydroxy diphenyl ketone, benzophenone, $\mathrm{TiCl}_{4}$, zinc power, 4-nitrobenzoic acid, palladium $10 \%$ activated carbon, trans-dichlorobis(triethylphosphine)palladium(II), propargyl bromide, and potassium carbonate were purchased from Aladdin and Sigma-Aldrich, and were used as received without further purification. Water was deionized with a Milli-Q SP reagent water system (Millipore) to a specific resistivity of $18.0 \mathrm{M} \Omega \mathrm{cm}$. Tetraphenylethene (TPE) based phenyl isocyanide monomer (TPE-NC) and catalysts (Cat. a and Cat. b) were synthesized in a similar way to that previously reported reference, ${ }^{1-6}$ the synthesis procedures were shown in Schemes S1, S2, and S3 in Supporting Information. The corresponding chemical structure of the mediators in each step were confirmed by ${ }^{1} \mathrm{H}$ NMR and FT-IR, as shown in Figures S1, S2, S3, S4, S13, and S14 in Supporting Information.

\section{Sample Preparation}

Synthesis of TPE Derivative Containing One Hydroxyl Group (TPE-OH). This compound was synthesized according to literature procedures with little modification. ${ }^{1-3}$ In a typical run, into a $500 \mathrm{~mL}$ round-bottom flask, zinc dust (6.0 g, $92 \mathrm{mmol})$, 4-hydroxy diphenyl ketone (4.4 g, $22 \mathrm{mmol})$, and diphenyl ketone (4.0 g, $22 \mathrm{mmol}$ ) were charged. The flask was then allowed to degas for $30 \mathrm{~min}$ by $\mathrm{N}_{2}$. After $200 \mathrm{~mL}$ of anhydrous 
THF added, the mixture was cooled to $-20{ }^{\circ} \mathrm{C}$, and $\mathrm{TiCl}_{4}(5 \mathrm{~mL}, 44 \mathrm{mmol})$ was injected slowly. The mixture was stirred for $0.5 \mathrm{~h}$ at $-20{ }^{\circ} \mathrm{C}$, and then refluxed at $55^{\circ} \mathrm{C}$ overnight. The reaction was quenched by aqueous $\mathrm{K}_{2} \mathrm{CO}_{3}$ solution (10\%) and extracted with diethyl ether. The organic phase was combined and washed with brine for three times. The mixture was dried over anhydrous $\mathrm{Na}_{2} \mathrm{SO}_{4}$ and the crude product was further purified by silica gel column chromatography using $\mathrm{CH}_{2} \mathrm{Cl}_{2}$ /petroleum ether (4:1, v/v) as eluent. After removing all the solvents, a yellow solid (TPE-OH; $3.62 \mathrm{~g}$, yielding: 43\%) was obtained. ${ }^{1} \mathrm{H}$ NMR (600 MHz, DMSO- $\left.d_{6}, 25^{\circ} \mathrm{C}\right): \delta 9.34(\mathrm{~s}, 1 \mathrm{H}, \mathrm{OH}), 7.06-7.14(\mathrm{~m}, 9 \mathrm{H}, \mathrm{ArH}), 6.93-6.98(\mathrm{~m}, 6 \mathrm{H}, \mathrm{ArH}), 6.73-6.75(\mathrm{~d}$, $2 \mathrm{H}, \mathrm{ArH}), 6.47-6.52(\mathrm{~d}, 2 \mathrm{H}, \mathrm{ArH})$. Tetrahydroxyl tetraphenylethene $\left(\mathrm{TPE}-\mathrm{OH}_{4}\right)$ was obtained through the reaction of two bis(4-hydroxyphenyl)methanones via the same method as the synthesis of TPE-OH described above. ${ }^{1} \mathrm{H}$ NMR $\left(600 \mathrm{MHz}, \mathrm{DMSO}-d_{6}, 25{ }^{\circ} \mathrm{C}\right) \delta: 9.21(\mathrm{~s}, 4 \mathrm{H}, \mathrm{OH}), 6.70(\mathrm{~d}, 8 \mathrm{H}, \mathrm{ArH}), 6.47(\mathrm{~d}, 8 \mathrm{H}$, ArH).

Synthesis of 4-(1,2,2-triphenylvinyl)phenyl 4-formamido benzoate (a). This compound was synthesized according to literature procedures with little modification. ${ }^{4,5}$ In a typical run, a $100 \mathrm{~mL}$ round-bottom flask was charged with 4-nitrobenzoic acid (0.37 g, $2.2 \mathrm{mmol})$, EDCI (0.42 g, $2.2 \mathrm{mmol})$, DMAP (0.12 g, 1.0 mmol), and dry $\mathrm{CH}_{2} \mathrm{Cl}_{2}(48 \mathrm{~mL})$. After the mixture was stirred at $0{ }^{\circ} \mathrm{C}$ for 0.5 hour under $\mathrm{N}_{2}$, TPE-OH $(0.7 \mathrm{~g}$, $2 \mathrm{mmol})$ in dry $\mathrm{CH}_{2} \mathrm{Cl}_{2}(2 \mathrm{~mL})$ was injected via a syringe. The reaction mixture was then allowed to stir at 0 ${ }^{\circ} \mathrm{C}$ for $0.5 \mathrm{~h}$ and warm to room temperature for another 5 hours. After removing the insoluble solids by suction filtration, the filtrate was washed with water $(3 \times 20 \mathrm{~mL})$. The organic layers were combined and dried over anhydrous $\mathrm{MgSO}_{4}$ and concentrated using a rotary evaporator. The crude product was further purified by silica gel column chromatography using $\mathrm{CH}_{2} \mathrm{Cl}_{2}$ as an eluent. After removing all the solvents, the final light yellow solid product was obtained $(0.94 \mathrm{~g}$, yielding: $91 \%) .{ }^{1} \mathrm{H} \mathrm{NMR}\left(600 \mathrm{MHz}, \mathrm{CDCl}_{3}, 25{ }^{\circ} \mathrm{C}\right): \delta$ $8.34(\mathrm{~s}, 4 \mathrm{H}, \mathrm{ArH}), 7.09-7.17(\mathrm{~m}, 11 \mathrm{H}, \mathrm{ArH}), 7.02-7.08(\mathrm{~m}, 6 \mathrm{H}, \mathrm{ArH}), 6.97-7.01$ (d, 2H, ArH).

Synthesis of 4-(1,2,2-triphenylvinyl)phenyl 4-aminobenzoate (b). Into a $100 \mathrm{~mL}$ round-bottom flask, 
compound $a(0.94 \mathrm{~g}, 1.9 \mathrm{mmol})$ and $10 \%$ palladium-activated carbon $(0.1 \mathrm{~g})$ were charged. After completely degassed for 30 min by $\mathrm{H}_{2}$, dry ethanol $(20 \mathrm{~mL})$ and dry $\mathrm{CH}_{2} \mathrm{Cl}_{2}(20 \mathrm{~mL})$ were injected to the mixture via a syringe. The mixture was allowed to stir at room temperature for $12 \mathrm{~h}$ under an atmosphere of $\mathrm{H}_{2}$. After filtration, the solvent was removed to give the white solid product $(0.85 \mathrm{~g}$, yielding: $90 \%) .{ }^{1} \mathrm{H}$ NMR $(600$ $\left.\mathrm{MHz}, \mathrm{CDCl}_{3}, 25{ }^{\circ} \mathrm{C}\right): \delta$ 7.95-7.99 (d, 2H, ArH), 7.08-7.16 (m, 9H, ArH), 7.01-7.08 (m, 8H, ArH), 6.93-6.97 (d, 2H, ArH), 6.65-6.69 (d, 2H, ArH), $4.12(\mathrm{br}, 2 \mathrm{H}, \mathrm{NH})$.

Synthesis of 4-(1,2,2-triphenylvinyl)phenyl 4-nitrobenzoate (c). A $50 \mathrm{~mL}$ round-bottom flask was charged with compound $b(0.85 \mathrm{~g}, 1.8 \mathrm{mmol})$ and dry ethyl acetate $(10 \mathrm{~mL})$, and the mixture was cooled to $0{ }^{\circ} \mathrm{C}$ in an ice-water bath. Another mixture of formic acid $(0.8 \mathrm{~mL})$ and acetic anhydride $(0.4 \mathrm{~mL})$, which had been prepared at room temperature for 30 min under $N_{2}$ in advance, was added slowly within 10 min. After the addition was completed, the reaction mixture was stirred at $0{ }^{\circ} \mathrm{C}$ for 0.5 hour and then allowed to warm to room temperature for another 2 hours. After the mixture was filtered, the filtrate was washed with $\mathrm{H}_{2} \mathrm{O}$ and brine, and then dried over anhydrous $\mathrm{MgSO}_{4}$. After the solvent was removed by evaporation, the crude product was purified by silica gel column chromatography using $\mathrm{CH}_{2} \mathrm{Cl}_{2}$ as an eluent. After removing all the solvents, the white solid product $(0.72 \mathrm{~g}$, yielding: $80 \%)$ was obtained. ${ }^{1} \mathrm{H} \mathrm{NMR}\left(600 \mathrm{MHz}, \mathrm{CDCl}_{3}, 25{ }^{\circ} \mathrm{C}\right)$ : $\delta 8.88(-\mathrm{NH}$ - in trans, $0.32 \mathrm{H}), 8.43(-\mathrm{NH}$ - in cis, $0.68 \mathrm{H}), 8.06(-\mathrm{CHO}$ in trans, $0.32 \mathrm{H}), 7.47(-\mathrm{CHO}$ in cis, $0.68 \mathrm{H}), 8.17-8.14(\mathrm{q}, 2 \mathrm{H}, \mathrm{ArH}), 7.68(\mathrm{ArH}$ to $-\mathrm{NH}$ - in cis, $1.24 \mathrm{H}), 7.18$ (ArH to $-\mathrm{NH}$ - in trans, $0.76 \mathrm{H})$, 7.02-7.15 (m, 17H, ArH), $6.97(\mathrm{~d}, 2 \mathrm{H}, \mathrm{ArH})$. The cis and trans conformers are tentatively assigned based on the reported literatures. ${ }^{7-8}$

Synthesis of TPE pendent phenyl isocyanide monomer (TPE-NC). In a typical run, a $100 \mathrm{~mL}$ round-bottom flask was charged with compound $c(0.72 \mathrm{~g}, 1.5 \mathrm{mmol})$, TEA $(1.5 \mathrm{~mL}, 13.5 \mathrm{mmol})$, and dry $\mathrm{CH}_{2} \mathrm{Cl}_{2}(30 \mathrm{~mL})$. The mixture was allowed to stir at $0{ }^{\circ} \mathrm{C}$ in an ice-water bath under $N_{2}$ for $0.5 \mathrm{~h}$. Then, a solution of triphosgene $(0.45 \mathrm{~g}, 1.5 \mathrm{mmol})$ in dry $\mathrm{CH}_{2} \mathrm{Cl}_{2}(10 \mathrm{~mL})$ was added dropwise to the mixture. After the addition 
was completed, the reaction mixture was stirred at $0{ }^{\circ} \mathrm{C}$ for 0.5 hour and allowed to warm to room temperature for 8 hours. After filtration, the solution was washed with aqueous $\mathrm{NaHCO}_{3}(2 \times 20 \mathrm{~mL})$ and brine $(2 \times 20 \mathrm{~mL})$ and dried over anhydrous $\mathrm{MgSO}_{4}$. After the solvent was concentrated, the crude product was purified by silica gel column chromatography using $\mathrm{CH}_{2} \mathrm{Cl}_{2} /$ petroleum ether $(1: 1$, v/v) as an eluent. After removing all the solvents, the final yellow product TPE-NC $(0.57 \mathrm{~g}$, yielding: $82 \%)$ was obtained. ${ }^{1} \mathrm{H}$ $\operatorname{NMR}\left(600 \mathrm{MHz}, \mathrm{CDCl}_{3}, 25^{\circ} \mathrm{C}\right): \delta 8.19-8.23(\mathrm{~d}, 2 \mathrm{H}, \mathrm{ArH}), 7.48-7.52(\mathrm{~d}, 2 \mathrm{H}, \mathrm{ArH}), 7.08-7.15(\mathrm{~m}, 11 \mathrm{H}, \operatorname{ArH})$, 7.02-7.08 (m, 6H, ArH), 6.95-6.98 (d, 2H, ArH). $\left.{ }^{13} \mathrm{C} \mathrm{NMR} \mathrm{(600} \mathrm{MHz,} \mathrm{CDCl}_{3}, 25{ }^{\circ} \mathrm{C}\right): \delta 167.80,163.49$, $149.07,143.61,143.58,143.48,141.84,141.67,139.95,132.57,131.47,131.46,131.42,131.37,130.56$, 127.93, 127.87, 127.79, 126.76, 126.72, 126.66, 120.72. FT-IR (KBr, $\left.25^{\circ} \mathrm{C}\right): 3099,3078,3053,3023,2126$, 1740, 1605, 1504, 1493, 1443, 1415, 1408, 1265, 1200, 1165, $1075 \mathrm{~cm}^{-1}$. HRMS m/z: calcd for $\mathrm{C}_{34} \mathrm{H}_{23} \mathrm{NO}_{2}$ $[\mathrm{M}+\mathrm{H}]^{+}, 478.1807$; found: $\mathrm{C}_{34} \mathrm{H}_{23} \mathrm{NO}_{2}, 478.1808$. Anal. Calcd (\%) for $\mathrm{C}_{34} \mathrm{H}_{23} \mathrm{NO}_{2}: \mathrm{C}, 85.51 ; \mathrm{H}, 4.85 ; \mathrm{N}$, 2.93; Found (\%): C, 85.54; H, 4.82; N, 2.95 .

Synthesis of (2-(4-(prop-2-yn-1-yloxy)phenyl)ethene-1,1,2-triyl)tribenzene (TPE-alkynyl). The reaction was performed in a similar way to the previously reported reference. ${ }^{6}$ A $50 \mathrm{~mL}$ round-bottom flask was charged with TPE-OH $(0.35 \mathrm{~g}, 1.0 \mathrm{mmol})$, potassium carbonate $(0.28 \mathrm{~g}, 2.0 \mathrm{mmol})$, and $20 \mathrm{~mL}$ of anhydrous $\mathrm{CH}_{3} \mathrm{CN}$. Then, propargyl bromide $(0.24 \mathrm{~g}, 2.9 \mathrm{mmol})$ was added dropwise, and the resulting mixture was heated to 70 ${ }^{\circ} \mathrm{C}$. After 24 hours, the solution was cooled to ambient temperature, and washed with saturated $\mathrm{NaHCO}_{3}$ and brine. The filtrate was concentrated and further purified by silica gel column chromatography using petroleum ether $/ \mathrm{CH}_{2} \mathrm{Cl}_{2}(4: 1, \mathrm{v} / \mathrm{v})$ as eluent. After dried over anhydrous $\mathrm{MgSO}_{4}$ and removing all the solvents, the final white solid product $(0.33 \mathrm{~g}$; yield: $85 \%)$ was obtained. ${ }^{1} \mathrm{H} \mathrm{NMR}\left(600 \mathrm{MHz}, \mathrm{CDCl}_{3}, 25{ }^{\circ} \mathrm{C}\right)$ :

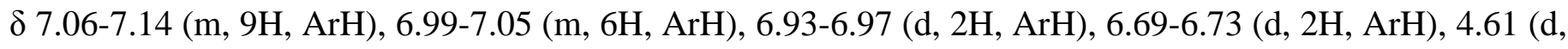
$2 \mathrm{H}, \mathrm{CH}_{2}$ ), 2.50 (t, 1H, -C $\equiv \mathrm{CH}$ ). 1,1,2,2-Tetrakis(4-(prop-2-yn-1-yloxy)phenyl)ethene (TPE-alkynyl 4 ) was

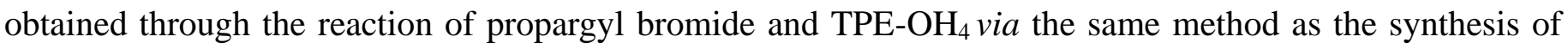


TPE-alkynyl described above. ${ }^{1} \mathrm{H}$ NMR $\left(600 \mathrm{MHz}, \mathrm{CDCl}_{3}, 25{ }^{\circ} \mathrm{C}\right): \delta 6.93(\mathrm{~d}, 8 \mathrm{H}, \mathrm{ArH}), 6.70(\mathrm{~d}, 8 \mathrm{H}, \mathrm{ArH})$, $4.61\left(\mathrm{~d}, 8 \mathrm{H}, \mathrm{CH}_{2}\right), 2.50(\mathrm{t}, 4 \mathrm{H},-\mathrm{C} \equiv \mathrm{CH})$.

Synthesis of TPE based Pd(II) catalyst (TPE-Cat. a). TPE-alkynyl (0.1 g, $0.26 \mathrm{mmol})$ was treated with trans-dichlorobis(triethylphosphine)palladium $(0.13 \mathrm{~g}, 0.3 \mathrm{mmol})$ in the presence of copper(I) chloride $(15$ $\mathrm{mg}, 0.15 \mathrm{mmol}$ ) as catalyst in $20 \mathrm{~mL}$ of anhydrous diethylamine and $20 \mathrm{~mL}$ of anhydrous $\mathrm{CH}_{2} \mathrm{Cl}_{2}$. The mixture was stirred at ambient temperature for 4 hours. After the solvent was removed under reduced pressure, the residue was further purified by silica gel column chromatography with petroleum ether/ethyl acetate $(4: 1, \mathrm{v} / \mathrm{v})$ as eluent. After removing all the solvents, TPE-Cat. a $(0.19 \mathrm{~g}$; yield: $92 \%)$ was obtained as a yellow solid. ${ }^{1} \mathrm{H}$ NMR (600 MHz, $\left.\mathrm{CDCl}_{3}, 25^{\circ} \mathrm{C}\right): \delta$ 7.07-7.14 (m, 9H, ArH), 6.98-7.06 (m, 6H, ArH), 6.89-6.92 (d, 2H, ArH), 6.69-6.73 (d, 2H, ArH), 4.64 (s, 2H, $\left.\mathrm{CH}_{2}\right), 1.80-1,88\left(\mathrm{~m}, 12 \mathrm{H}, \mathrm{PCH}_{2} \mathrm{CH}_{3}\right), 1.07-1.13$ (m, $\left.18 \mathrm{H}, \mathrm{PCH}_{2} \mathrm{CH}_{3}\right) .{ }^{13} \mathrm{C} \mathrm{NMR}\left(600 \mathrm{MHz}, \mathrm{CDCl}_{3}, 25{ }^{\circ} \mathrm{C}\right): \delta 156.77,144.09,144.04,143.96,140.54,139.99$, $135.94,132.25,131.33,131.31,127.69,127.60,127.55,126.34,126.23,114.02,100.40-100.32(\mathrm{t})$, 91.96-91.75(t), 57.57, 15.31-15.12(t), 8.32. ${ }^{31} \mathrm{P}$ NMR (121.5 MHz, $\left.\mathrm{CDCl}_{3}, 25{ }^{\circ} \mathrm{C}\right): \delta 17.74$. FT-IR (KBr, 25 $\left.{ }^{\circ} \mathrm{C}\right): 2960,2926,2875,2854,2131,1604,1506,1457,1413,1377,1033,1018 \mathrm{~cm}^{-1} . \mathrm{HRMS} \mathrm{m} / z:$ calcd for $\mathrm{C}_{41} \mathrm{H}_{51} \mathrm{ClOP}_{2} \mathrm{Pd}[\mathrm{M}+\mathrm{H}]^{+}$, 763.2216; found: $\mathrm{C}_{41} \mathrm{H}_{51} \mathrm{ClOP}_{2} \mathrm{Pd}$, 763.2192. Anal. Calcd (\%) for $\mathrm{C}_{41} \mathrm{H}_{51} \mathrm{ClOP}_{2} \mathrm{Pd}$ : C, 64.48; H, 6.73; Found (\%): C, 64.50; H, 6.69. TPE based Pd(II) catalyst (TPE-Cat. b) was obtained through the reaction of TPE-alkynyl 4 and trans-dichlorobis(triethylphosphine)palladium via the same method as the synthesis of TPE-Cat. a described above. ${ }^{1} \mathrm{H}$ NMR $\left(600 \mathrm{MHz}, \mathrm{CDCl}_{3}, 25{ }^{\circ} \mathrm{C}\right): \delta 6.85-6.89(\mathrm{~d}$, 8H, ArH), 6.65-6.68 (d, 8H, ArH), $4.62\left(\mathrm{~s}, 8 \mathrm{H}, \mathrm{CH}_{2}\right), 1.83-1.88\left(\mathrm{~m}, 48 \mathrm{H}, \mathrm{PCH}_{2} \mathrm{CH}_{3}\right), 1.07-1.13(\mathrm{~m}, 72 \mathrm{H}$, $\left.\mathrm{PCH}_{2} \mathrm{CH}_{3}\right) .{ }^{13} \mathrm{C} \mathrm{NMR}\left(600 \mathrm{MHz}, \mathrm{CDCl}_{3}, 25{ }^{\circ} \mathrm{C}\right): \delta 156.61,138.41,136.97,132.34,113.95,100.43-100.36(\mathrm{t})$, 92.05-91.83(t), 57.75, 15.41-15.22(t), 8.41. ${ }^{31} \mathrm{P}$ NMR (121.5 MHz, $\left.\mathrm{CDCl}_{3}, 25{ }^{\circ} \mathrm{C}\right): \delta 17.70$. FT-IR $(\mathrm{KBr}, 25$ $\left.{ }^{\circ} \mathrm{C}\right): 2963,2927,2876,2854,2131,1605,1507,1456,1412,1377,1289,1253,1216,1173,1033,1017 \mathrm{~cm}^{-1}$. HRMS m/z: calcd for $\mathrm{C}_{86} \mathrm{H}_{144} \mathrm{Cl}_{4} \mathrm{O}_{4} \mathrm{P}_{8} \mathrm{Pd}_{4}[\mathrm{M}+\mathrm{H}]^{+}$, 2060.3944; found: $\mathrm{C}_{86} \mathrm{H}_{144} \mathrm{Cl}_{4} \mathrm{O}_{4} \mathrm{P}_{8} \mathrm{Pd}_{4}, 2060.3878$. Anal. 
Calcd (\%) for $\mathrm{C}_{86} \mathrm{H}_{144} \mathrm{Cl}_{4} \mathrm{O}_{4} \mathrm{P}_{8} \mathrm{Pd}_{4}: \mathrm{C}, 50.21 ; \mathrm{H}, 7.06$; Found (\%): C, 50.24; H, 7.03.

Polymerization of Phenyl Isocyanide Derivatives (TPE-NC) with Pd(II) Complex as Catalyst. The polymerization was performed according to our previously reported reference. ${ }^{3,4}$ Take TPE-Cat. a as an example, typically, a $10 \mathrm{~mL}$ oven-dried flask was charged with TPE-NC monomers (382 mg, $0.8 \mathrm{mmol})$ and THF $(2.0 \mathrm{~mL})$. To this stirring mixture was added a solution of TPE-Cat. a $\left(7.6 \mathrm{mg}, 0.01 \mathrm{mmol} ;[\mathrm{M}]_{0} /[\mathrm{I}]_{0}=\right.$ 80) in THF $(0.2 \mathrm{~mL})$ via syringe at ambient temperature. After stirred at $50{ }^{\circ} \mathrm{C}$ for 24 hours, the reaction mixture was cooled to ambient temperature and precipitated into a large amount of $n$-hexane. The final polymers were collected by centrifugation and dried in vacuum at ambient temperature overnight. SEC: $M_{\mathrm{n}}$ $=31.0 \mathrm{kDa}, M_{\mathrm{w}} / M_{\mathrm{n}}=1.18$, the degree of polymerization (DP) of polymer was calculated to be $\sim 65$, namely, poly(TPE-NC) ${ }_{65}$. The chemical structure was confirmed by ${ }^{1} \mathrm{H}$ NMR and shown in Figure S8 in Supporting Information. Following the same method, poly(TPE-NC) $)_{n}$ with other DP values $(14,32$, and 105) were obtained. The characterization data were summarized in Table 1 (runs 1-4). Moreover, polymerization of TPE-NC monomer with TPE-Cat. $b$ as catalyst was also performed, and the characterization data of TPE-[poly(TPE-NC) $\left.{ }_{20}\right]_{4}$ was summarized in Table 1 (run 5).

\section{REFERENCES}

(1) Yu, C.; Wu, Y.; Zeng, F.; Li, X.; Shi, J.; Wu, S. Biomacromolecules 2013, 14, 4507-4514

(2) Yu, W.-H.; Chen, C.; Hu, P.; Wang, B.-Q.; Redshaw, C.; Zhao, K.-Q. RSC Adv. 2013, 3, 14099-14105.

(3) Song, N.; Chen, D. X.; Qiu, Y. C.; Yang, X. Y.; Xu, B.; Tian, W. J.; Yang, Y. W.; Chem. Commun., 2014, $50,8231-8234$.

(4) Shi, S. Y.; He, Y. G.; Chen, W. W.; Liu, N.; Zhu, Y. Y.; Ding, Y. S.; Yin, J.; Wu, Z. Q. Macromol. Rapid Commun. 2015, 36, 1511-1520.

(5) Li, W.; He, Y. G.; Shi, S. Y.; Liu, N.; Zhu, Y. Y.; Ding, Y. S.; Yin, J.; Wu, Z. Q. Polym. Chem. 2015, 6, 2348-2355.

(6) Xue, Y.-X.; Zhu, Y.-Y.; Gao, L.-M.; He, X.-Y.; Liu, N.; Zhang, W.-Y.; Yin, J.; Ding, Y.; Zhou, H.; Wu, Z.-Q. J. Am. Chem. Soc., 2014, 136, 4706-4713. 
(7) Wu, Z. Q.; Nagai, K.; Banno, M.; Okoshi, K.; Onitsuka, K.; Yashima, E. J. Am. Chem. Soc. 2009, 131, 6708.

(8) Amabilino, D. B.; Ramos, E.; Serrano, J. L.; Sierra, T.; Veciana, J. J. Am. Chem. Soc. 1998, 120, 9126. 


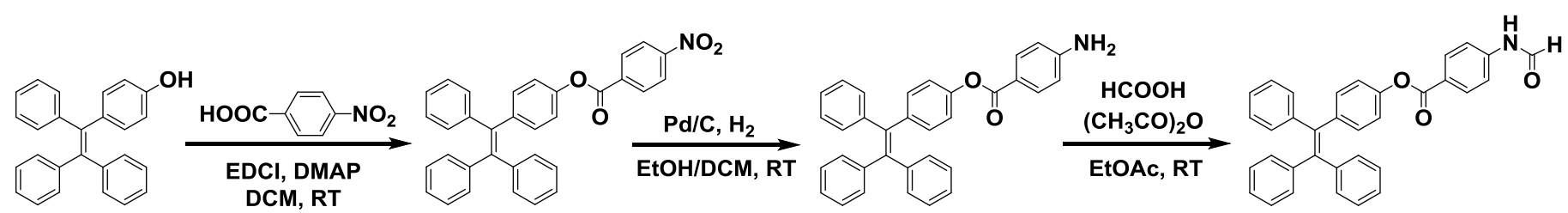

(TPE-OH) (b) (c)
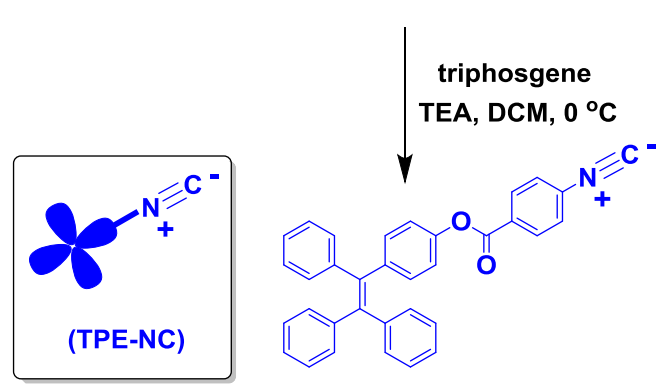

Scheme S1. Synthetic routes employed for the preparation of tetraphenylethene (TPE) pendent phenyl isocyanide monomer (TPE-NC). 


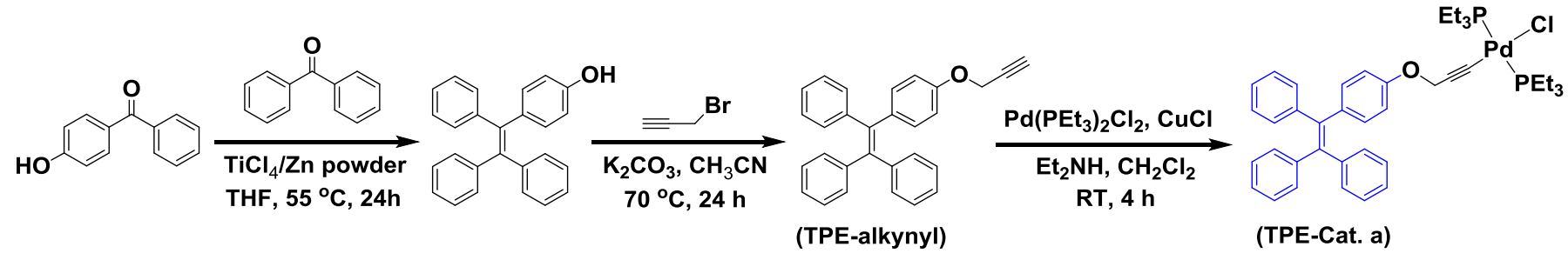

Scheme S2. Synthetic routes employed for the preparation of TPE based mono-functional Pd(II) catalyst (TPE-Cat. a). 


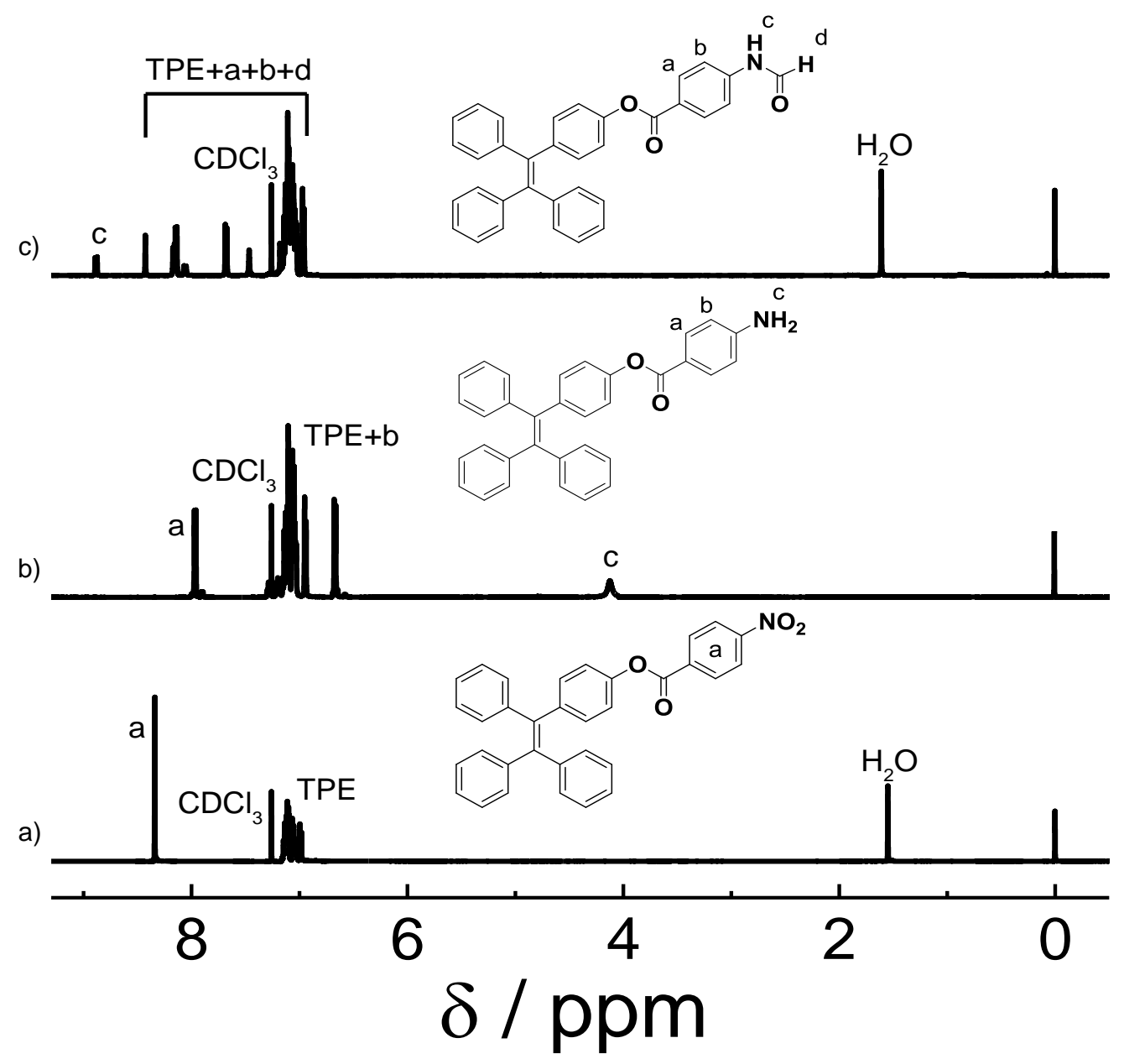

Figure S1. ${ }^{1} \mathrm{H}$ NMR spectra obtained for mediators: (a) 4-(1,2,2-triphenylvinyl)phenyl 4-nitrobenzoate, (b) 4-(1,2,2-triphenylvinyl)phenyl 4-aminobenzoate, and (c) 4-(1,2,2-triphenylvinyl)phenyl 4-formamido benzoate in the preparation of TPE-NC monomers. 


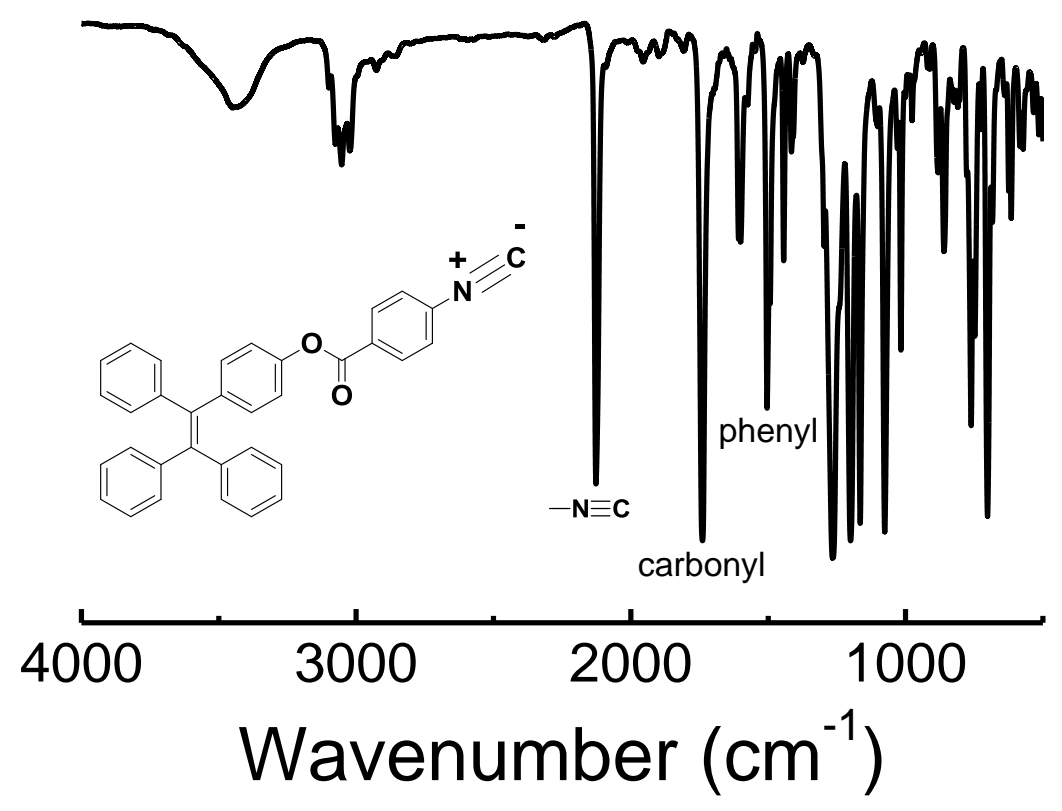

Figure S2. FT-IR spectrum obtained for TPE-NC monomers at $25^{\circ} \mathrm{C}$ using $\mathrm{KBr}$ pellets. 


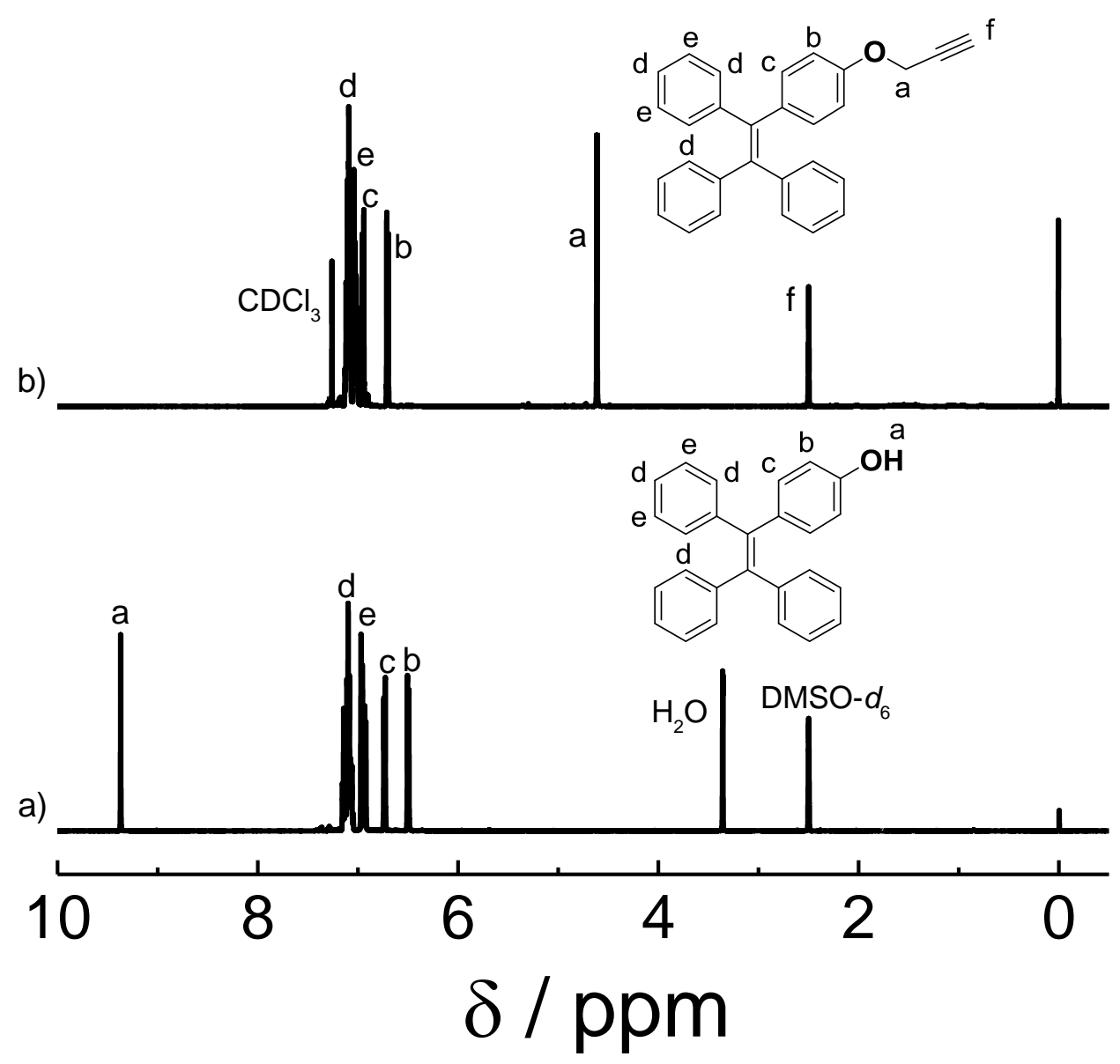

Figure S3. ${ }^{1}$ H NMR spectra obtained for mediators: (a) 4-(1,2,2-triphenylvinyl)phenol (TPE-OH) and (b) (2-(4-(prop-2-yn-1-yloxy)phenyl)ethene-1,1,2-triyl)tribenzene in the preparation of TPE based Pd(II) catalyst (TPE-Cat. a). 


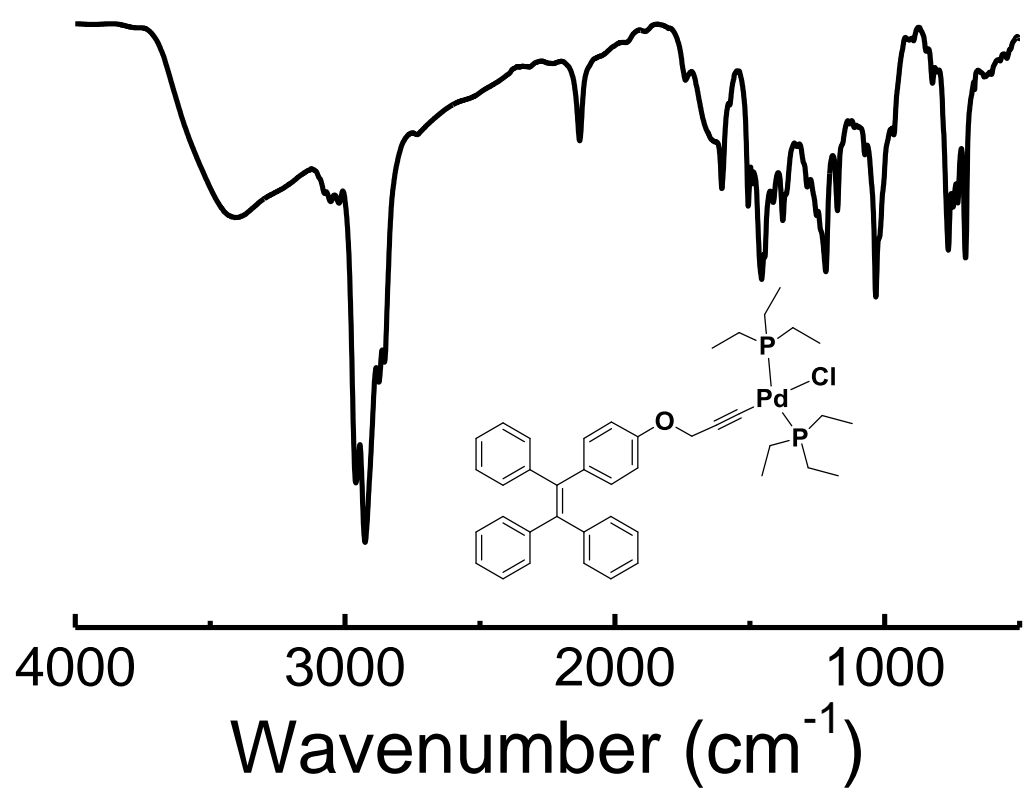

Figure S4. FT-IR spectrum obtained for TPE-Cat. a at $25^{\circ} \mathrm{C}$ using $\mathrm{KBr}$ pellets. 


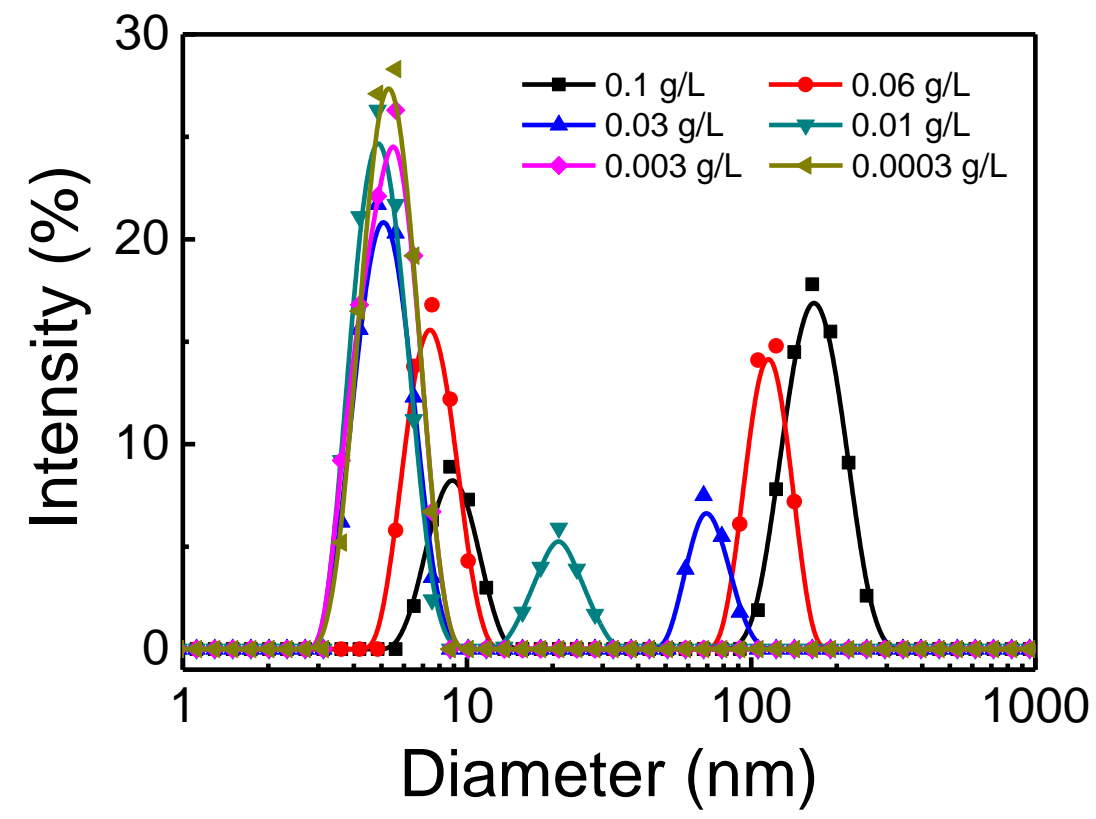

Figure S5. Dynamic light scattering (DLS) spectra obtained for TPE-NC monomers in THF with concentration range of 0.0003-0.1 g/L. 

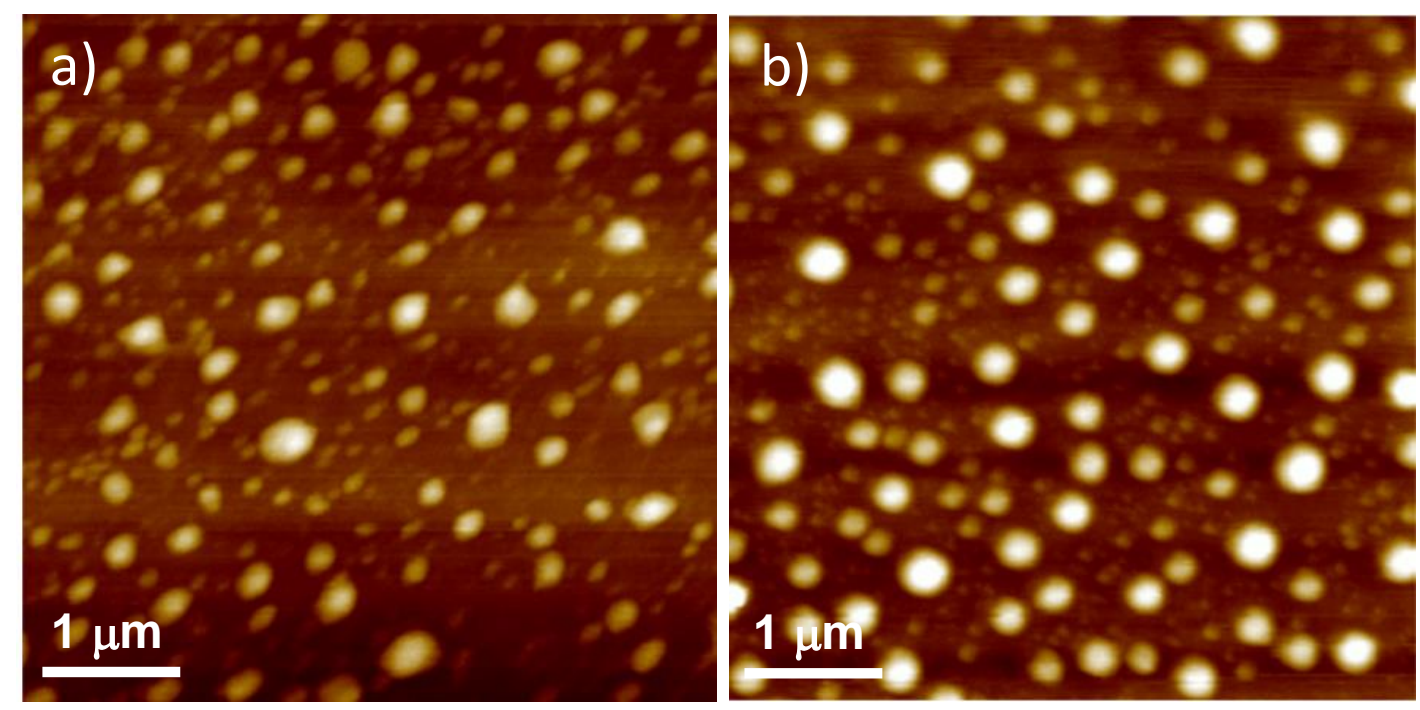

Figure S6. Atomic force microscopy (AFM) images obtained for TPE-Cat. a nanoaggregates dried from THF solution with different concentrations: (a) $0.06 \mathrm{~g} / \mathrm{L}$, (b) $0.1 \mathrm{~g} / \mathrm{L}$. 

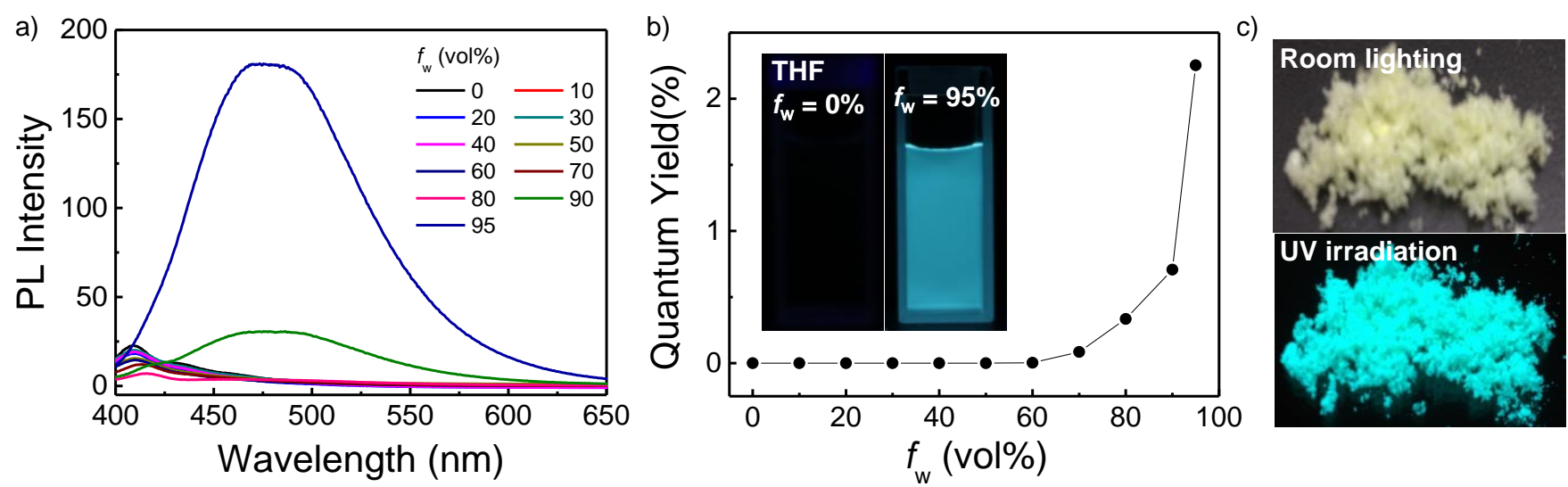

Figure S7. Fluorescent spectra (a) recorded for TPE-Cat. a in THF/water mixtures with different $f_{\mathrm{w}}$, and the relative quantum yields (b) determined as a function of $f_{\mathrm{w}}$. The inserted fluorescent photographs were taken under $365 \mathrm{~nm}$ UV irradiation from a hand-held UV lamp, the concentration were fixed at $1 \times 10^{-5} \mathrm{M}$. (c) Photographs taken for solid powers of TPE-Cat. a under room light or $365 \mathrm{~nm}$ UV irradiation. 


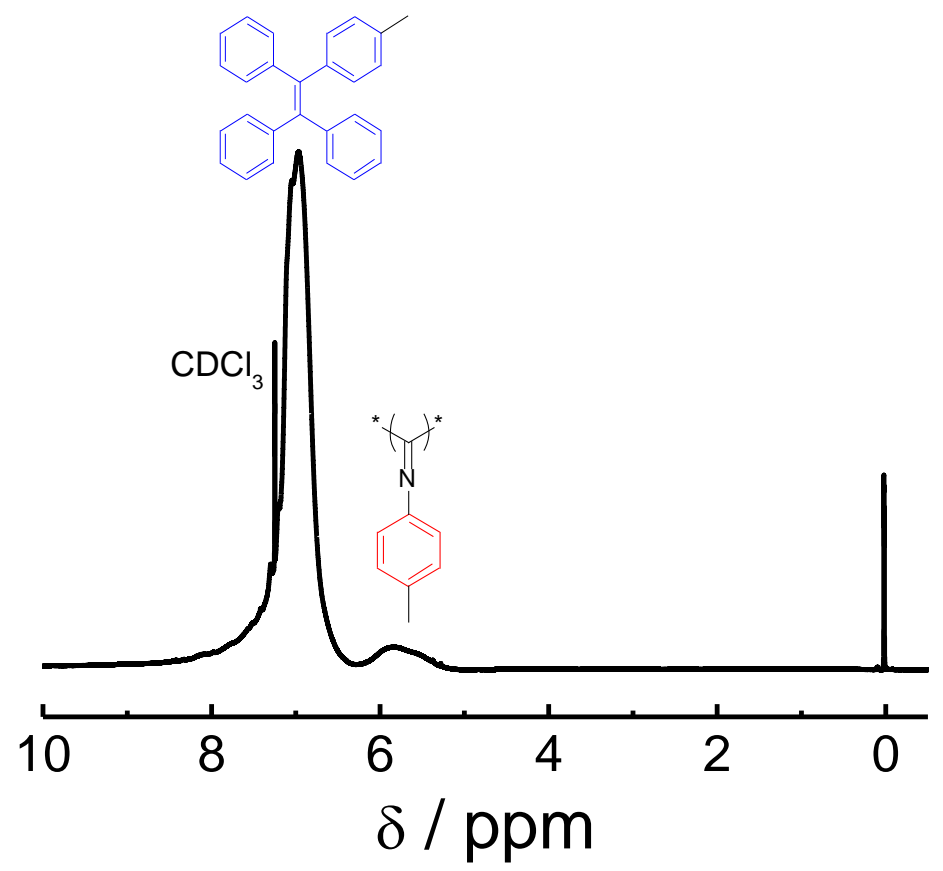

Figure S8. ${ }^{1} \mathrm{H}$ NMR spectrum obtained for poly(TPE-NC) 65 polymers in $\mathrm{CDCl}_{3}$ at room temperature. 


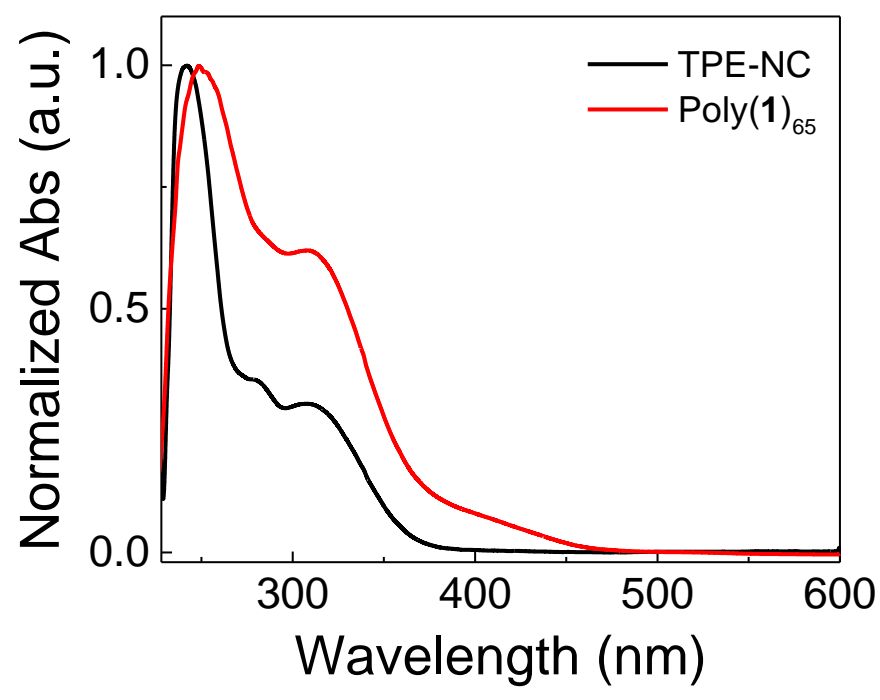

Figure S9. Normalized UV-vis spectra recorded for TPE-NC monomers and corresponding poly(TPE-NC) 65 polymers in THF. The concentration were fixed at $0.06 \mathrm{~g} / \mathrm{L}$. 

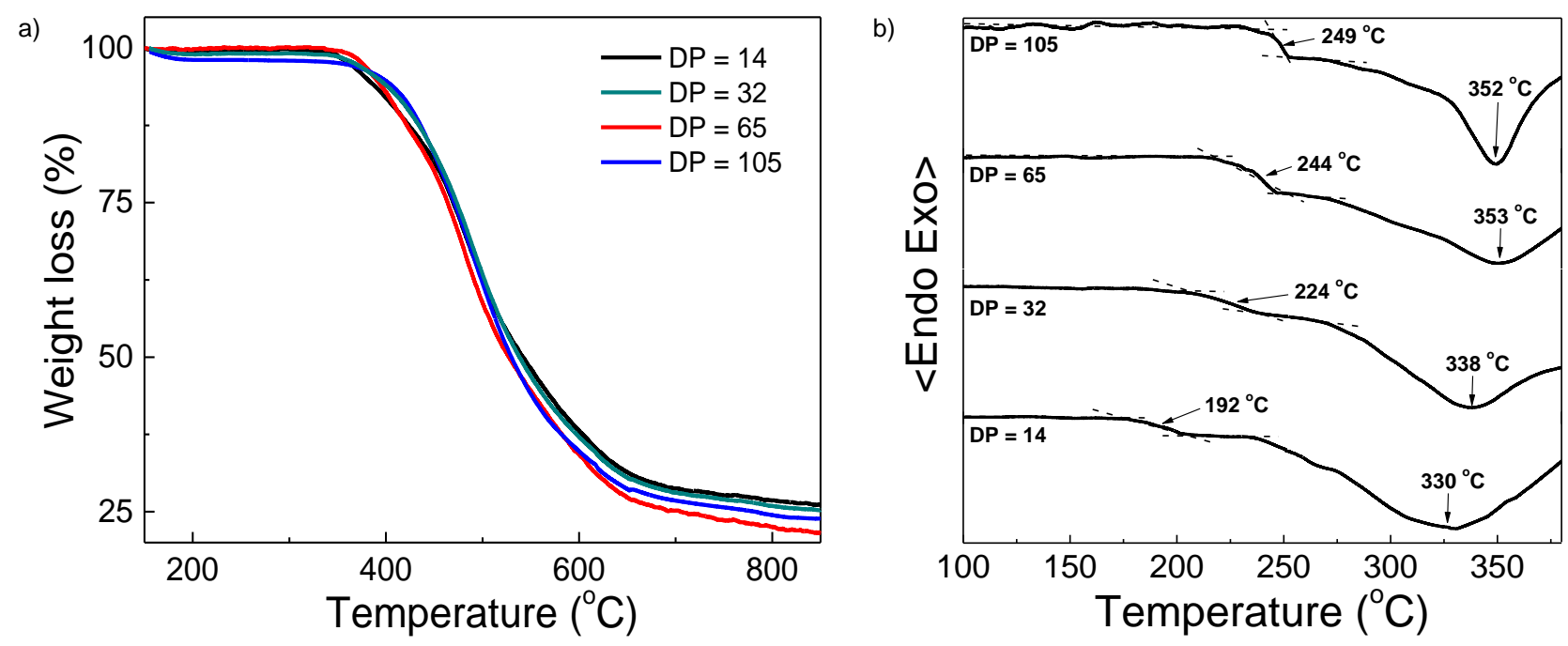

Figure S10. (a) TGA and (b) DSC curves recorded for poly(TPE-NC) $)_{n}$ with different DP values (runs 1-4 in Table 1) under $\mathrm{N}_{2}$ atmosphere at a heating rate of $10{ }^{\circ} \mathrm{C} \mathrm{min}^{-1}$. 

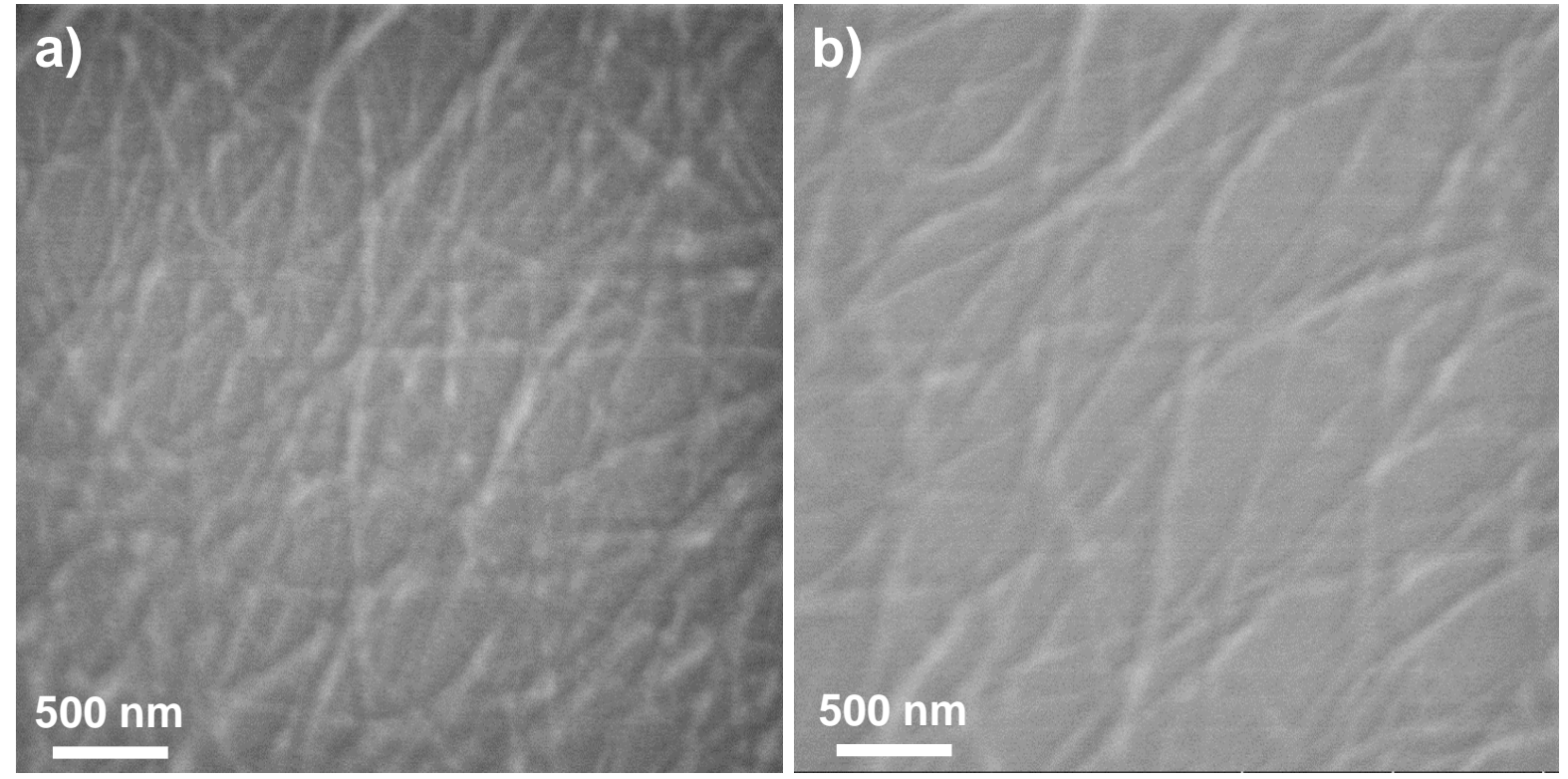

Figure S11. SEM images obtained for poly(TPE-NC) $)_{n}$ with different DP values dried from THF solution: (a) $\mathrm{DP}=65$ and (b) DP $=105$. All the concentration of the THF solutions were fixed at $0.1 \mathrm{~g} / \mathrm{L}$. 


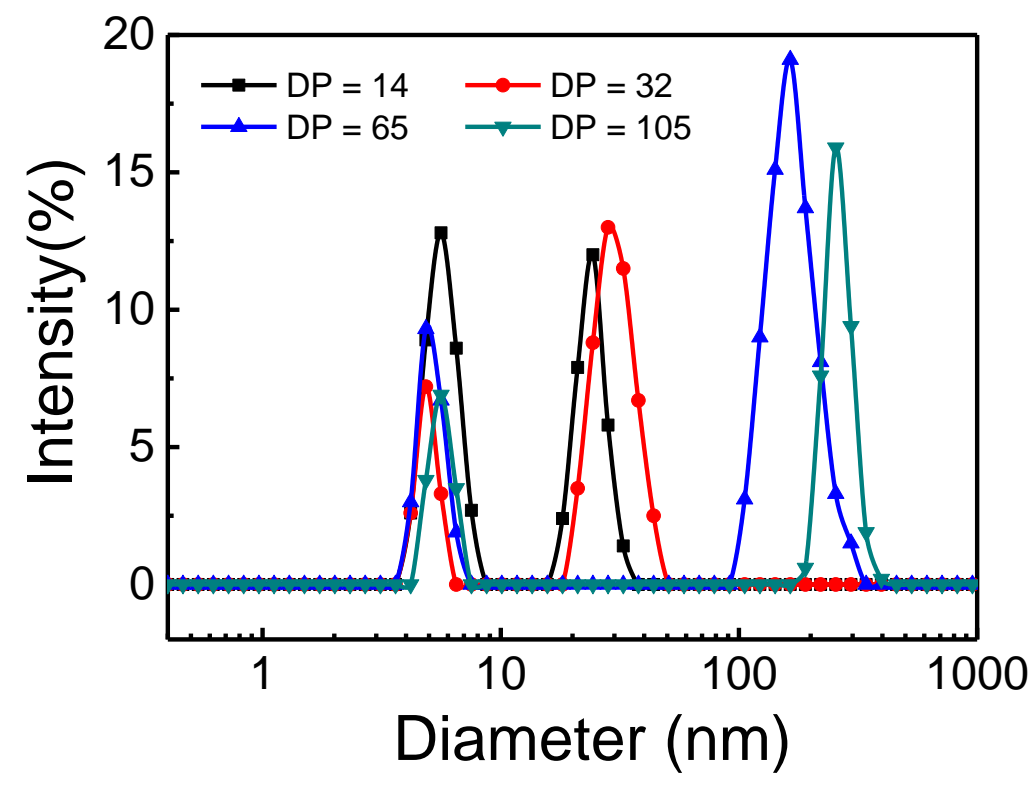

Figure S12. DLS spectra obtained for poly(TPE-NC) $)_{n}$ with different DP values in THF solution. All the concentration of the THF solutions were fixed at $0.1 \mathrm{~g} / \mathrm{L}$. 

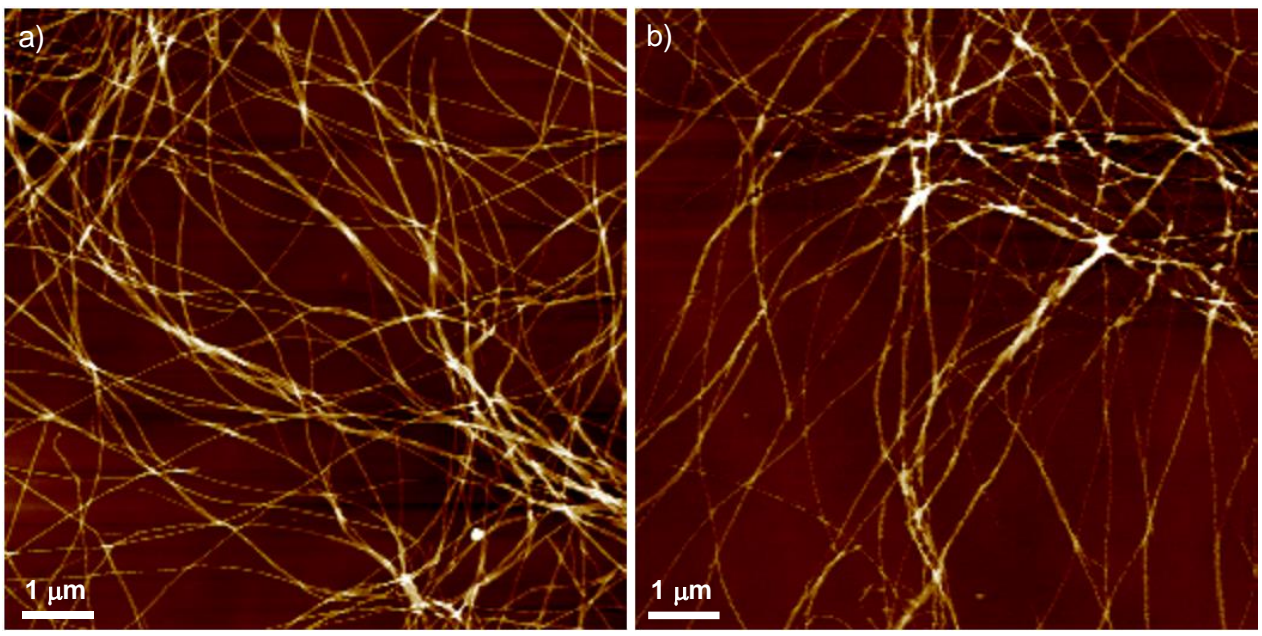

Figure S13. AFM images obtained for poly $(\mathrm{TPE}-\mathrm{NC})_{\mathrm{n}}$ with different $\mathrm{DP}$ values dried from $\mathrm{CHCl}_{3}$ solution: (a) $\mathrm{DP}=65$ and (b) $\mathrm{DP}=105$. The concentration was fixed at $0.1 \mathrm{~g} / \mathrm{L}$. 


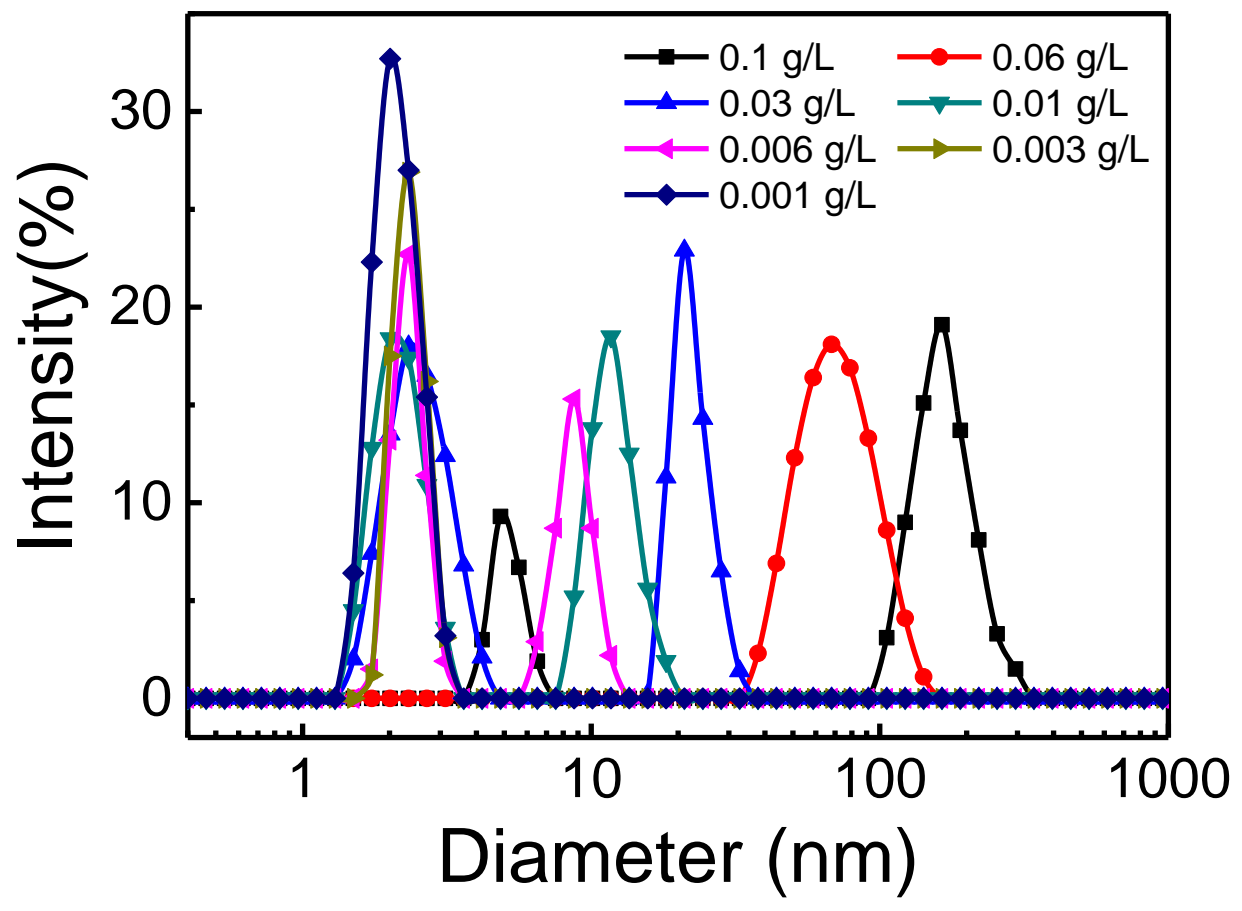

Figure S14. DLS spectra obtained for poly(TPE-NC) $)_{65}$ in THF solution as a function of concentration. 


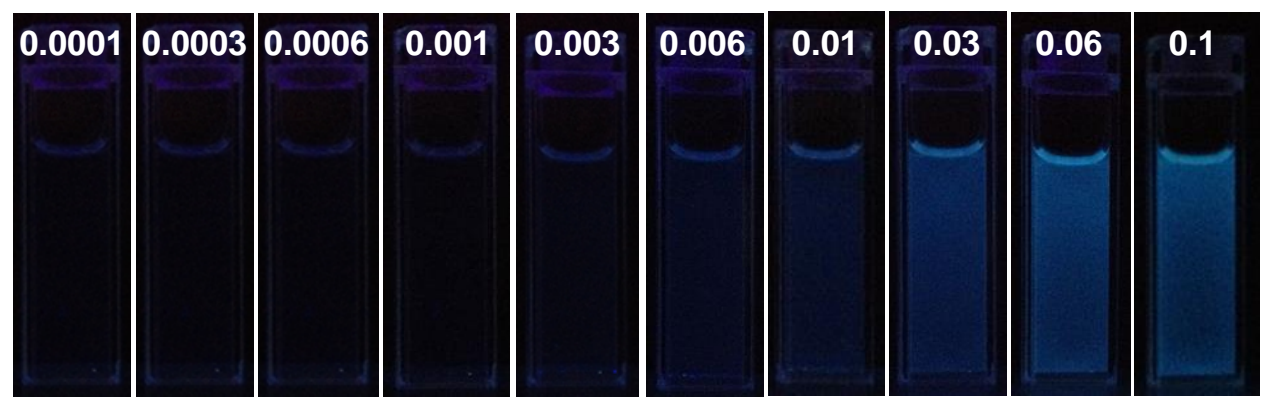

Figure S15. Fluorescent photographs taken for THF solution of poly(TPE-NC) 65 polymers with different concentrations (0.0001-0.1 g/L) under $365 \mathrm{~nm}$ UV irradiation from a hand-held UV lamp. 


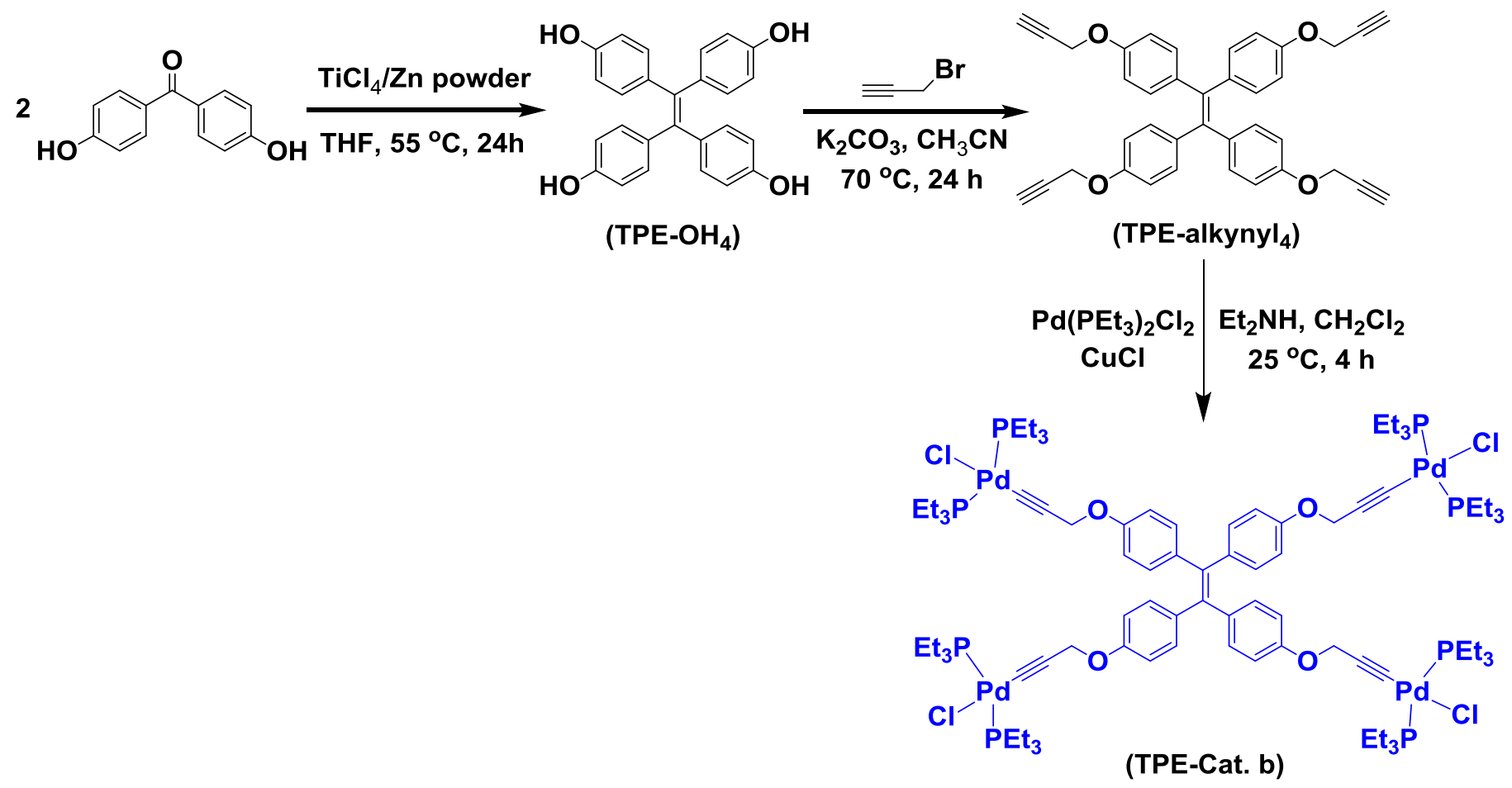

Scheme S3. Synthetic routes employed for the preparation of TPE based tetra-functional Pd(II) catalyst (TPE-Cat. b). 


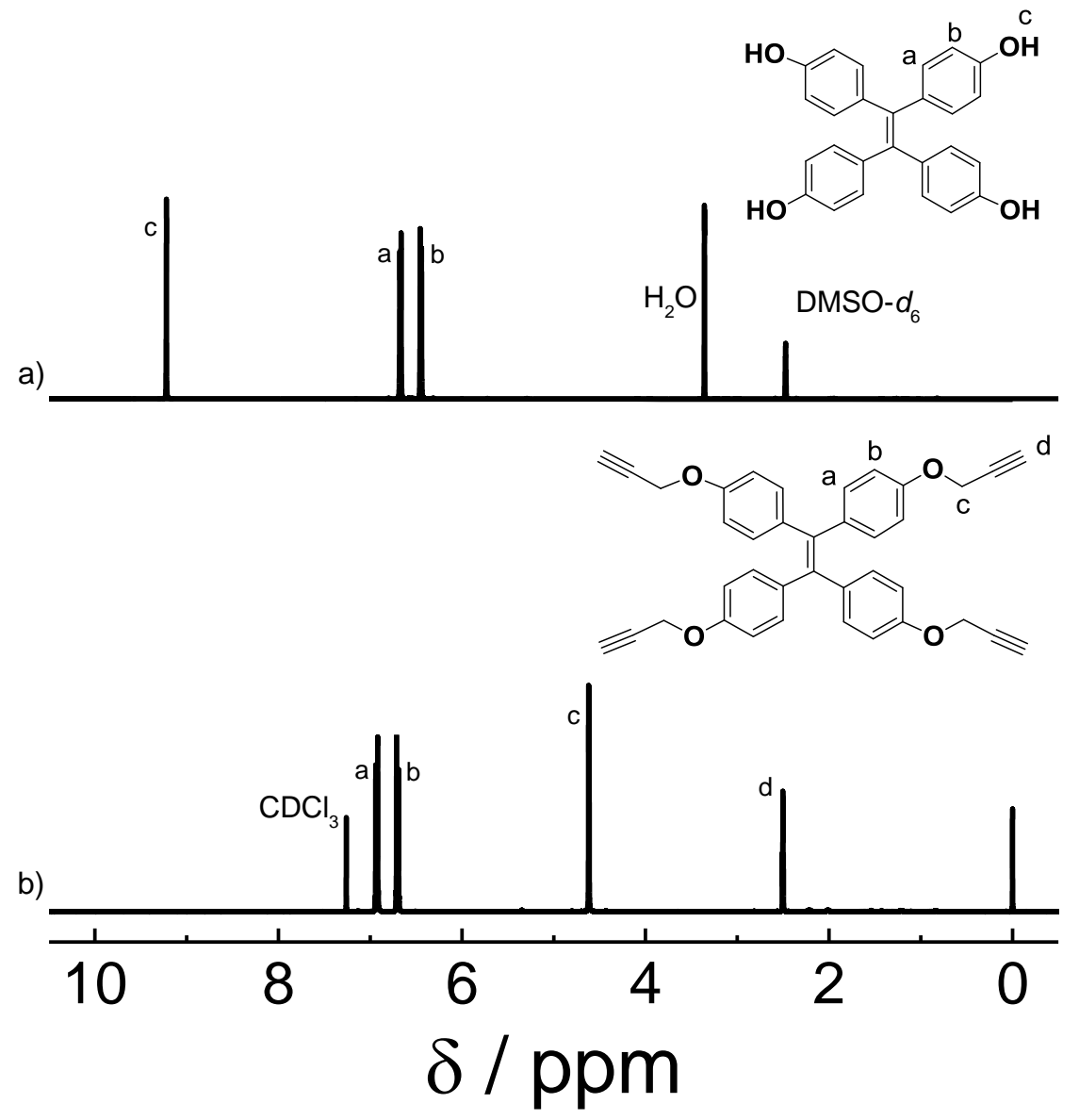

Figure S16. ${ }^{1}$ H NMR spectra obtained for mediators: (a) 4,4',4",4"'-(ethene-1,1,2,2-tetrayl)tetraphenol and (b) 1,1,2,2-tetrakis(4-(prop-2-yn-1-yloxy)phenyl)ethene in the preparation of tetra-functional TPE-Cat. b. 


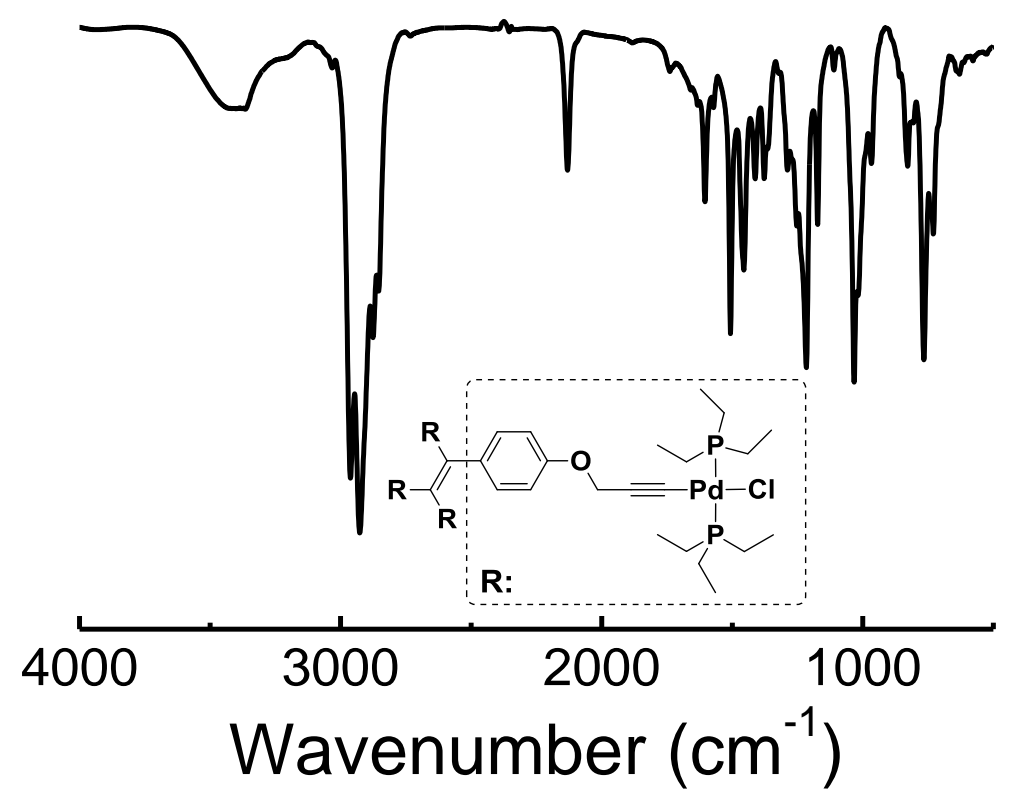

Figure S17. FT-IR spectrum obtained for tetra-functional TPE-Cat. b at $25^{\circ} \mathrm{C}$ using $\mathrm{KBr}$ pellets. 


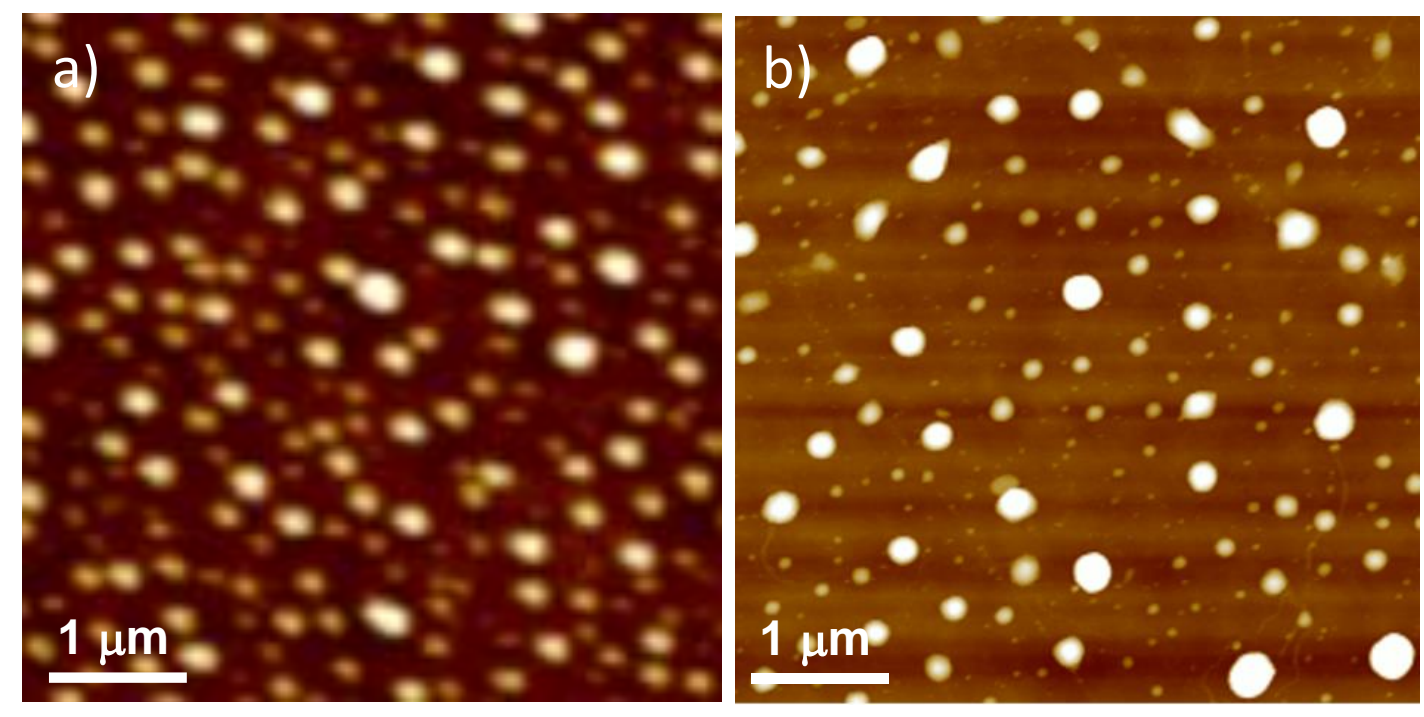

Figure S18. AFM images obtained for TPE-Cat. b nanoaggregates dried from THF solution with different concentrations: (a) $0.06 \mathrm{~g} / \mathrm{L}$, (b) $0.1 \mathrm{~g} / \mathrm{L}$. 

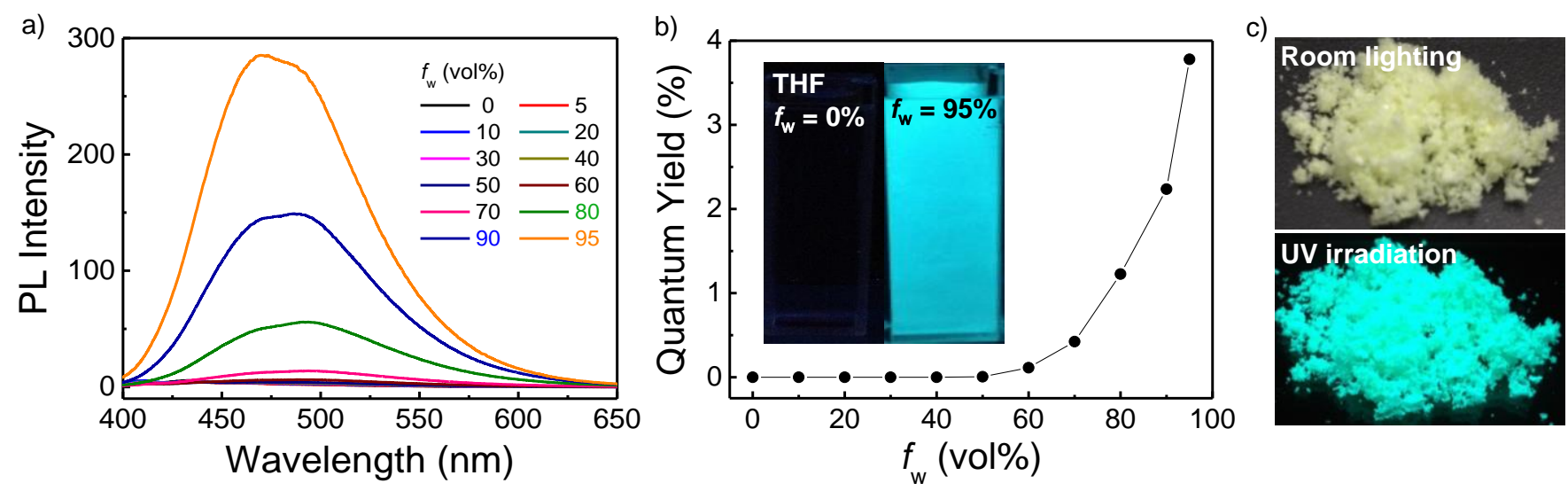

Figure S19. Fluorescent spectra (a) recorded for TPE-Cat. b in THF/water mixtures with different $f_{\mathrm{w}}$, and the relative quantum yields (b) determined as a function of $f_{\mathrm{w}}$. The inserted fluorescent photographs were taken under $365 \mathrm{~nm}$ UV irradiation from a hand-held UV lamp, the concentration were fixed at $1 \times 10^{-5} \mathrm{M}$. (c) Photographs taken for solid powers of TPE-Cat. b under room light or $365 \mathrm{~nm}$ UV irradiation. 


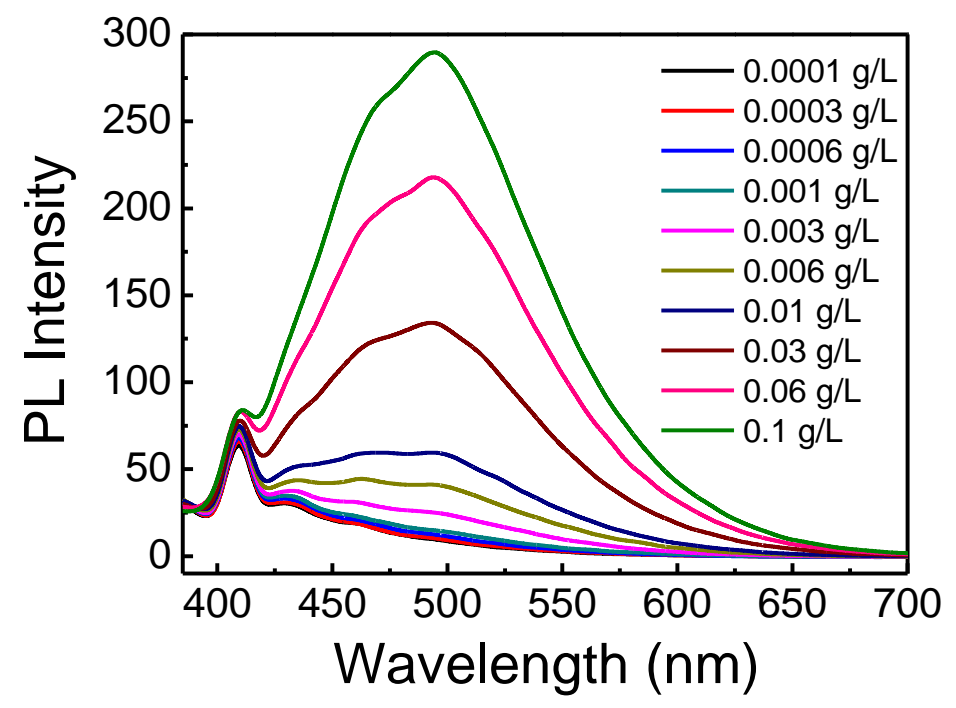

Figure S20. Fluorescent spectra recorded for THF solution of four-armed TPE-[poly(TPE-NC) $\left.{ }_{20}\right]_{4}$ polymers as a function of concentration. 


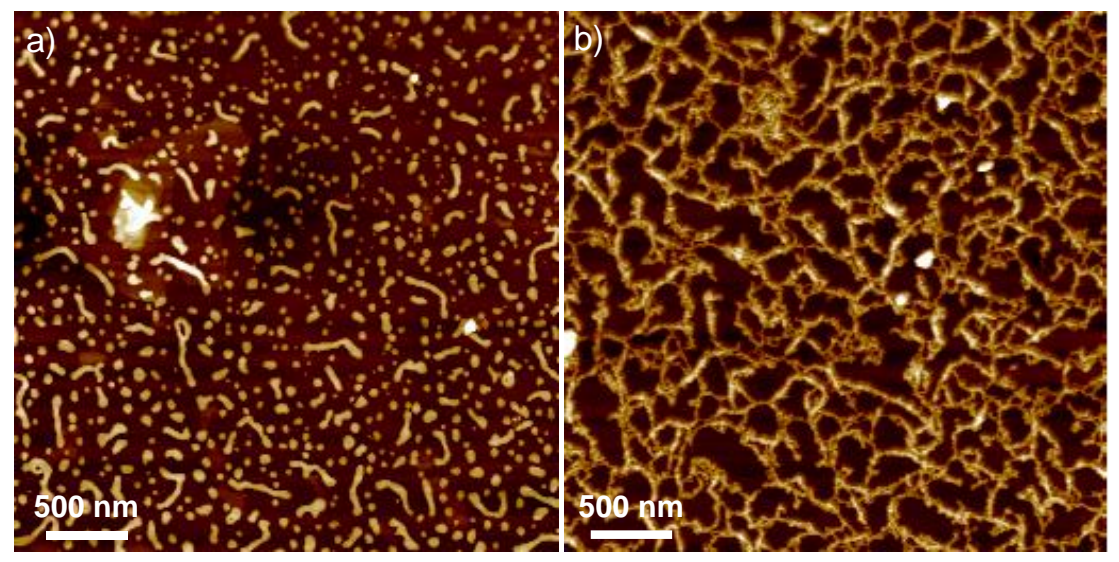

Figure S21. AFM images obtained for four-armed TPE-[poly(TPE-NC) $\left.{ }_{20}\right]_{4}$ polymers dried from $\mathrm{CHCl}_{3}$ solution with different concentrations: (a) $0.05 \mathrm{~g} / \mathrm{L}$ and (b) $0.1 \mathrm{~g} / \mathrm{L}$. 
a)
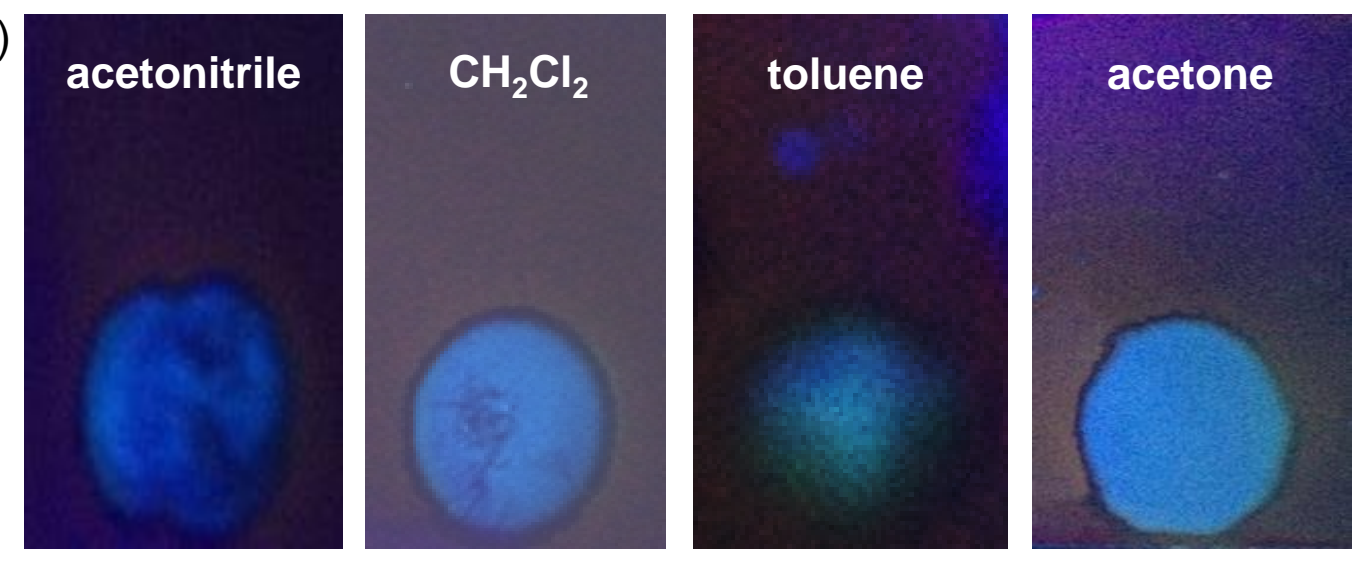

b)
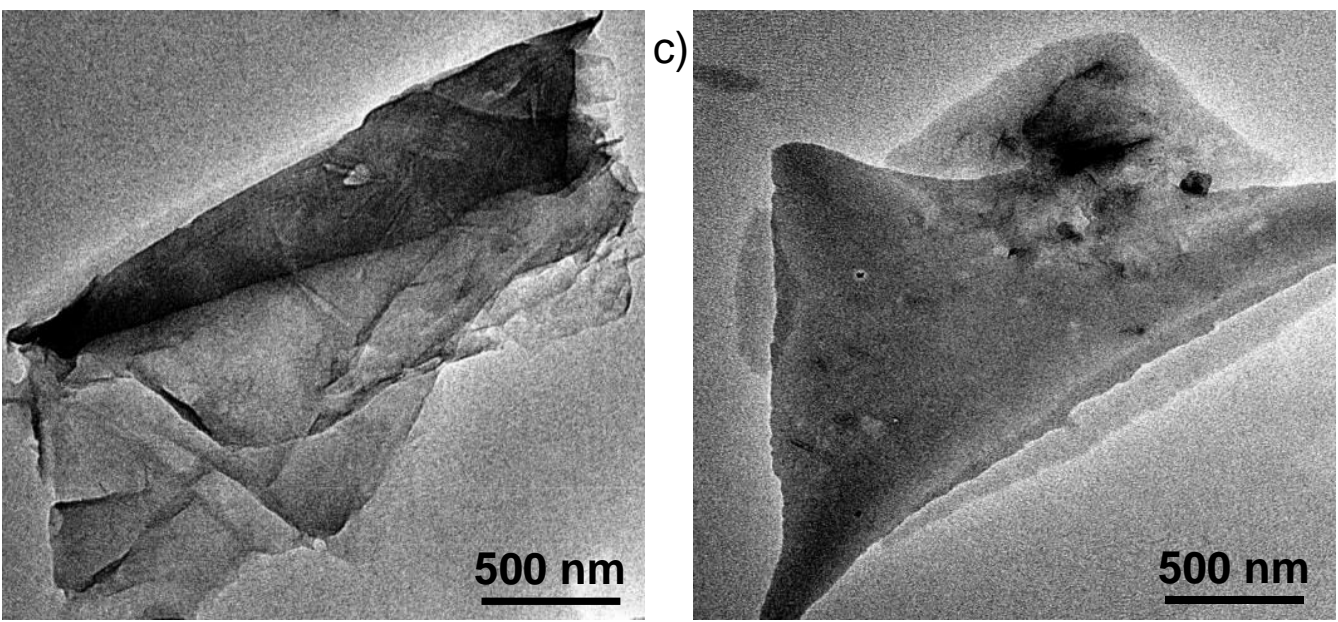

Figure S22. (a) Fluorescent photographs taken for poly(TPE-NC) $)_{65}$ film on glass sheet after partial fumigation by acetonitrile, $\mathrm{CH}_{2} \mathrm{Cl}_{2}$, toluene, and aceton at room temperature. TEM images taken for THF dispersions $(0.2 \mathrm{~g} / \mathrm{L})$ of GO and poly(TPE-NC) $)_{105}(\mathrm{P} 4 ; \mathrm{b})$ or TPE-[poly(TPE-NC) $\left.)_{20}\right]_{4}(\mathrm{P} 5$; c), respectively, after sonication in an ultrasonic bath for 30 seconds. 